NBER WORKING PAPER SERIES

\title{
MODELING THE IMPACTS OF AGRICULTURAL SUPPORT POLICIES ON EMISSIONS FROM AGRICULTURE
}

\author{
David Laborde \\ Abdullah Mamun \\ Will Martin \\ Valeria Piñeiro \\ Rob Vos \\ Working Paper 27202 \\ http://www.nber.org/papers/w27202 \\ NATIONAL BUREAU OF ECONOMIC RESEARCH \\ 1050 Massachusetts Avenue \\ Cambridge, MA 02138 \\ May 2020
}

This technical paper is part of the input for a World Bank study on "Environmental Impacts of Agricultural Support: Aligning Food Security and Climate Protection Objectives." It was prepared as an output of the CGIAR Research Program on Policies, Institutions and Markets (PIM). Funding for this research was provided by The World Bank and PIM. The authors are grateful to Madhur Gautam from the World Bank for comments on an earlier draft of this paper. The views expressed herein are those of the authors and do not necessarily reflect the views of the National Bureau of Economic Research.

NBER working papers are circulated for discussion and comment purposes. They have not been peer-reviewed or been subject to the review by the NBER Board of Directors that accompanies official NBER publications.

(C) 2020 by David Laborde, Abdullah Mamun, Will Martin, Valeria Piñeiro, and Rob Vos. All rights reserved. Short sections of text, not to exceed two paragraphs, may be quoted without explicit permission provided that full credit, including $(\subset)$ notice, is given to the source. 
Modeling the Impacts of Agricultural Support Policies on Emissions from Agriculture

David Laborde, Abdullah Mamun, Will Martin, Valeria Piñeiro, and Rob Vos

NBER Working Paper No. 27202

May 2020

JEL No. F1,F13,F18,O13,O24,O44,Q01,Q17,Q18,Q2,Q28,Q5,Q55,Q58

\begin{abstract}
To understand the impacts of support programs on global emissions, this paper considers the impacts of domestic subsidies, price distortions at the border, and investments in emissionreducing technologies on global greenhouse gas (GHG) emissions from agriculture. In a step towards a full evaluation of the impacts, it uses a counterfactual global model scenario showing how much emissions from agricultural production would change if agricultural support were abolished worldwide. The analysis indicates that, without subsidies paid directly to farmers, output of some emission-intensive activities and agricultural emissions would be smaller. Without agricultural trade protection, however, emissions would be higher. This is partly because protection reduces global demand more than it increases global agricultural supply, and partly because some countries that currently tax agriculture have high emission intensities. Policies that directly reduce emission intensities yield much larger reductions in emissions than those that reduce emission intensities by increasing overall productivity because overall productivity growth creates a rebound effect by reducing product prices and expanding output. A key challenge is designing policy reforms that effectively reduce emissions without jeopardizing other key goals such as improving nutrition and reducing poverty. This analysis is an important building block towards a full understanding the impacts of reforms to agricultural support on mitigation of greenhouse gas emissions and adaptation to climate change. That full analysis is being undertaken in current work incorporating land use changes and examining the impacts of specific reforms on mitigation, resilience and economic outcomes.
\end{abstract}

David Laborde

International Food Policy Research Institute 1201 Eye St NW

Washington, DC 20005

d.laborde@cgiar.org

Abdullah Mamun

International Food Policy Research Institute 1201 I St NW

Washington, DC 20005

a.mamun@cgiar.org

Will Martin

International Food Policy Research Institute 1201 I St NW

Washington, DC 20005

W.Martin@cgiar.org
Valeria Piñeiro

International Food Policy Research Institute 1201 I St NW

Washington, DC 20005

v.pineiro@cgiar.org

Rob Vos

International Food Policy Research Institute 1201 I St NW

Washington, DC 20005

r.vos@cgiar.org 


\section{Modeling the Impacts of Agricultural Support Policies on Emissions from}

Agriculture

Agricultural production is strongly affected by climate change but is, at the same time, a major contributor to climate change - with agriculture and land use accounting for around a quarter of total global emissions of greenhouse gases (Tubiello 2019). World agriculture is also strongly affected by support policies that affect the composition and location of output and the approaches used for production. One key question is what impact these interventions have on greenhouse gas (GHG) emissions from agriculture by providing incentives to lower or higher emission-intensive crops or livestock production. A related question is how these support measures might be reformed so they could not only support farm incomes and productivity growth, but also provide incentives for reducing greenhouse gas emissions.

The farm sector in the 51 countries included in the OECD's annual policy monitoring program received an average of US $\$ 440$ billion per year in the form of market price support and direct subsidies between 2016 and 2018, equal to about 15 percent of gross farm receipts (OECD 2019). These countries also spent US\$105 billion per year on what OECD terms General Services Support, that is policies designed to create enabling conditions for agriculture, such as agricultural innovation systems, sanitary and phytosanitary standards and rural infrastructure. The US\$440 billion in market price support includes direct subsidies that are "coupled" to output and create incentives for producers to expand output (US\$176 bn); and "decoupled" subsidies that seek to avoid altering production incentives (US\$64 bn).

Recent work by Mamun, Martin and Tokgoz (2019) has examined these types of agricultural support and their relationship to GHG emissions from agriculture. This study highlighted a few key facts:

- the extreme concentration of agricultural emissions by commodity - with beef, dairy and rice accounting for over 80 percent of agricultural GHG emissions;

- a substantial fraction of emissions comes from land use and land use change;

- the production of these emission-intensive goods is often heavily supported using marketprice-support (MPS) measures, thereby creating strong incentives to increase output but reduce consumption of agricultural commodities in the protecting country. 
Further analysis is needed, however, to be confident about the implications of reforming agricultural support measures for overall GHG emissions. Some of the key factors that need to be considered include: (i) the average rate of support to agriculture, (ii) differences between types of support, (iii) differences in rates of support across commodities, and (iv) impacts of support on the production methods and processes.

The average rate of support to agriculture matters because high rates of support are likely to attract resources into agriculture, increase output and, at constant technology, to increase emissions from agricultural activity. The resulting increase in agricultural output is likely small, because total agricultural production can only be increased by raising total agricultural land use or substituting other inputs for land. Increases in agricultural land use, in turn, are likely to induce very large one-off increases in emissions as land is cleared for use in agriculture, particularly if land is cleared by burning forests.

The type of support matters because of its influence on overall incentives to both producers and consumers. Some distortions to agricultural incentives, such as coupled subsidies paid by governments to producers, provide incentives to producers without providing any incentives for consumers to reduce consumption. Other types of support, such as market-price support (MPS) in the form of tariff or non-tariff barriers, provide incentives for producers to increase output, while encouraging consumers in protected markets to reduce consumption of the protected good. This suggests that MPS, while more trade-distorting than coupled subsidies, may have a smaller impact on global agricultural output and emissions. Provision of MPS may even reduce global agricultural output and emissions. Consider, for example, protection provided in countries with low agricultural production. The import protection will raise consumer prices in that region and, hence, lower consumption and global output. Decoupled support aims to provide support to farmers without creating incentives to change output levels and - to the extent that it is truly decoupled - can be ignored for our purposes.

Differences in rates of support across commodities may have important impacts on overall emissions given large differences in the emission intensity ${ }^{1}$ of commodities. As noted by Mamun, Martin and Tokgoz (2019), individual agricultural commodities are likely to be more responsive to differentials in agricultural support rates than is overall agricultural output to the average rate of agricultural support. This is because increasing total agricultural output requires

\footnotetext{
${ }^{1}$ Defined as the quantity of GHG emitted per unit of output.
} 
either changing the amount of agricultural land, or intensifying production on existing land through increased input use, such as fertilizer and labor. Of course, the output mix can be changed by switching to other crops or livestock production on existing land. Mamun, Martin and Tokgoz (2019) concluded that, on average, the existing structure of agricultural support provides little incentive to farmers to switch from high to low emission-intensive commodities.

Differences in agricultural support across countries also matter for global outcomes. Mamun, Martin and Tokgoz (2019) show that the emission intensities of production for the same commodities differ substantially between rich and poor countries and, also, within those groups Historically, support to farmers has been higher in high-income countries than in poor, creating incentives to expand production in lower-emission countries. However, in recent years, MPS rates in high-income countries have declined, while they have increased in developing countries (Laborde and Mamun 2019). The key point for this study is that support in countries with high emission intensities increases global output in those countries and, other things being equal, increases global emissions per unit of global output.

Support intended to influence production practices and processes, such as subsidies on fertilizers, pesticides or improved seeds, also matter. In practice, these mostly aim to stimulate agricultural production which may induce more emissions unless improved practices are more resource efficient. Higher input use, such as in the case of fertilizer, may be an additional source of GHG emissions, though improved, climate-resilient seeds may prove more environmentfriendly. Some support programs, like the reformed Common Agricultural Policy of the EU, condition access to support to compliance with environment-friendly production and land conservation practices.

OECD's General Services Support Estimate (GSSE), includes measures, such as agricultural research, development, and training, that aim to raise agricultural productivity. While these measures are not part of the widely reported Producer Support Estimate (PSE), they can be critical to productivity growth and, hence, to incomes of farmers and food prices for consumers. Productivity gains tend to reduce the emission intensities of agricultural products, for instance, through changes in production processes that also reduce emission intensities (see, for example, Mernit 2018), or through more efficient use of intermediate inputs.

This paper is designed to complement existing studies on the measurement of GHG emissions from agriculture and the implications of reform. One key set of studies (see, for 
example, Tubiello 2019) assesses the extent of emissions from agriculture. A second group of studies (see, for example, Jensen et al. 2019, Fellman et al. 2019, and OECD 2019) examines the implications of potential policies such as carbon and consumption taxes for reducing GHG emissions from global agriculture. A third group of studies focusses reform of agricultural support policies in the European Union, using the CAPRI model (see, for example, Himics et al. 2018). A fourth group of studies (e.g., Henderson and Lankoski 2019) examines the potential implications of policy reform in OECD countries and/or in specific agricultural sub-sectors (Gerber et al. 2013). A fifth group of studies examines options for creating a more sustainable food system (eg, Searchinger et al 2019).

This study is a first stage of analysis of the impacts of reforming agricultural subsidies for adaptation to and mitigation of climate change, holding agricultural land use constant. In it, we use as wide a coverage as possible of agricultural policy measures and emission sources and focus primarily on the implications of current agricultural support policies for emission outcomes. In doing so, we undertake a careful quantitative analysis of the impacts of incentives on agricultural outputs and emissions using IFPRI's global computable general equilibrium model, MIRAGRODEP. This model-based analysis provides an opportunity to consider all the influences outlined above - impacts on overall output, differences in incentives across countries, differences in incentives across commodities, and differences in the technology used for production. It also allows us to examine the extent and potential implications of environmental conditionalities incorporated in producer support measures. We take into account not just the total emissions per unit of output, but also the source of those emissions - whether they are, for instance, from enteric fermentation by ruminants or from fertilizer use. The analysis also provides a framework for assessing the potential impact of innovations that reduce the emissionintensity of production, such as by reducing emissions of GHGs from enteric fermentation in ruminants (Boadi et al. 2004; Haque 2018).

The next section of this paper explains the process by which we developed the database of emissions that allowed us to track emissions by source and product. The third section details the approach we used to represent the distortions to agricultural incentives examined in the study. The fourth section discusses the simulations used to assess the impacts of changes in agricultural incentives on global emissions. The fifth section considers the links between changes 
in productivity and global emissions. The sixth section discusses the approach to policy given policy makers' multiple goals and the instruments considered in this paper.

\section{The Emissions Database}

Our focus in this paper is on agricultural emissions. It is important first to put these emissions in the broader context of emissions from all sources, such as energy, industry, land use and transport. To ensure comparability of the data, we draw on the FAOSTAT (2019) data, for which the most recent comparable on agriculture and non-agriculture are for 2010.

Figure 1. Emissions from Agriculture and Land Use relative to Other Emissions, 2010

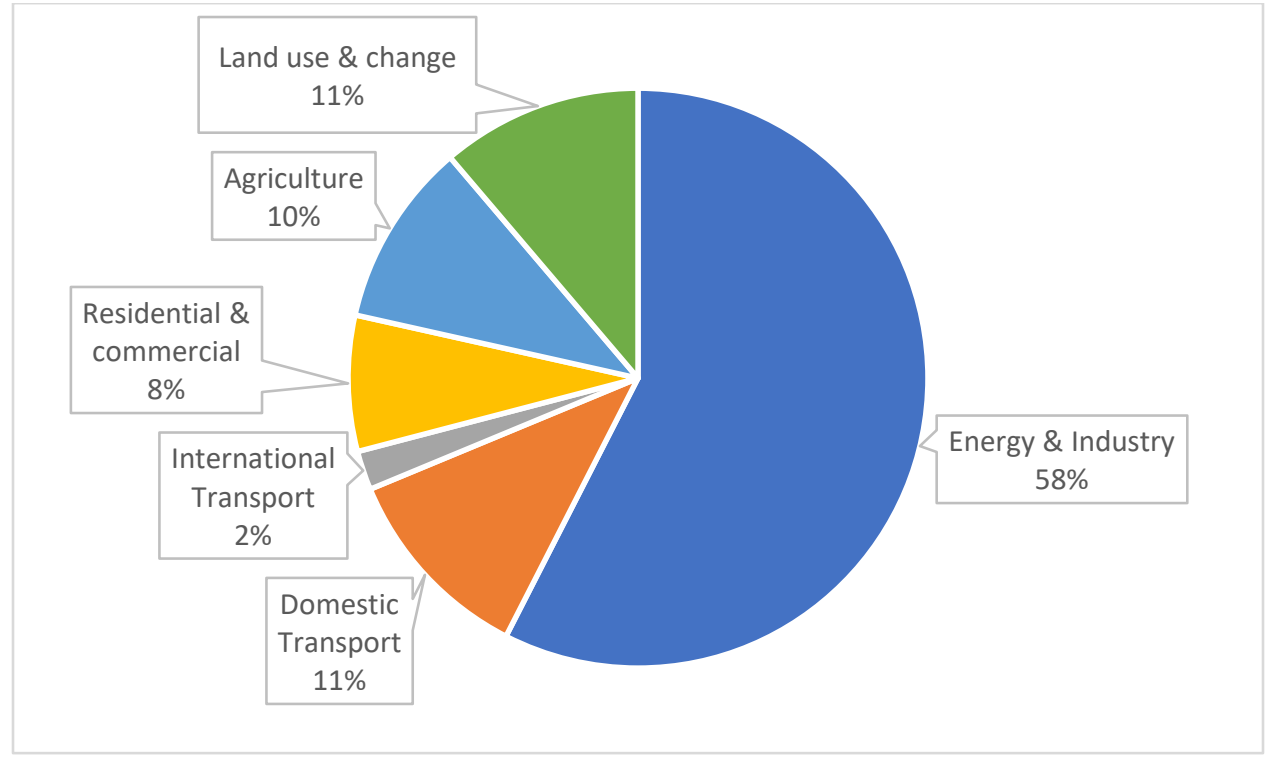

Source: FAO. Note. Shares are percent of total emissions, excluding sequestration by forests.

A key feature of the Figure 1 is the importance of agriculture and land use change in total emissions, with over 20 percent of all GHG emissions. At 21 percent of the total, it is small relative to energy and industry, but much larger than the emissions associated with transport and residential/commercial use, that receive enormous attention in popular discussions. While it was discussed in the original UN Framework Convention on Climate Change (UN 1992), it was seriously under-represented in subsequent commitments, partly because of poor and inconsistent data on the extent of the problem. With the ready availability of estimates through FAOSTAT 
(see Tubiello 2019), the basic information needed to analyze the problem and approaches to its resolution is now available. Emissions from agriculture and land use change are much more comprehensively included in the Paris Agreement than in earlier accords (Vermeulen 2016).

Because the modeling framework we use for this paper covers only ongoing emissions from agriculture, we focus only on the agriculture component of emissions.

An important distinction between agriculture and other sources of emissions is the much greater relative importance of the relatively short-lived methane $\left(\mathrm{CH}_{4}\right)$, with a lifespan of around 12 years in the atmosphere, and nitrous oxide $\left(\mathrm{N}_{2} \mathrm{O}\right)$, with a lifespan of 120 years, emissions from agriculture (Houghton et al. 1996). As shown in Table 1, these two gases account for almost all the emissions from agriculture, while the emissions from most other sectors are dominated by carbon dioxide $\left(\mathrm{CO}_{2}\right)$. The Global Warming Potential (GWP) conversion factors used in the database are the IPCC measures (Houghton et al. 1996, p22) that compare the GWP of each gas after 100 years. These sum the impacts of a unit emission over that period, substantially reducing the impact of methane relative to $\mathrm{CO}_{2}$ because it has its impact only over around 12 years (Harvey 1993). These measures are appropriate for estimating impacts on climate change over the next 100 years. However, the impact of $\mathrm{CH}_{4}$ emissions will be larger in shorter periods, where more of the impact of the $\mathrm{CH}_{4}$ remains, and greater over periods longer than 100 years because the atmospheric $\mathrm{CH}_{4}$ level would remain constant with constant annual emissions, while the $\mathrm{CO}_{2}$ concentration would keep rising ${ }^{2}$.

Table 1. Emissions by type of Greenhouse Gas, 2010

\begin{tabular}{|c|c|c|c|c|c|}
\hline & Methane & $\begin{array}{l}\text { Carbon } \\
\text { Dioxide }\end{array}$ & F-Gases & Nitrous Oxide & Total \\
\hline Agriculture & 56.4 & 0.0 & 0.0 & 43.6 & 100.0 \\
\hline Land Use & 5.2 & 93.3 & 0.0 & 1.5 & 100.0 \\
\hline Energy & 11.8 & 87.5 & 0.0 & 0.8 & 100.0 \\
\hline Residential/Commercial & 7.2 & 90.4 & 0.0 & 2.4 & 100.0 \\
\hline Industry/Other/Waste & 25.2 & 49.5 & 16.2 & 9.1 & 100.0 \\
\hline International Transport & 0.2 & 99.0 & 0.0 & 0.8 & 100.0 \\
\hline Domestic Transport & 0.0 & 99.7 & 0.0 & 0.3 & 100.0 \\
\hline Sources total & 15.1 & 77.0 & 1.7 & 6.2 & 100.0 \\
\hline
\end{tabular}

Source: FAOSTAT.

\footnotetext{
${ }^{2}$ Where timing issues are important, Edwards and Trancik (2014) propose alternative approaches.
} 
For the present analysis, a database is required that links decisions on agricultural outputs and inputs with their associated emissions. For this, we build on the FAOSTAT global database (Tubiello 2019; FAO 2019) that links GHG emissions to output of commodities and the production processes used in countries. Holding emissions per unit of output and input constant allows us to develop a fixed-coefficient model of emissions. Our modeling framework also provides the option for us to vary the relationship between outputs and inputs in response to changes in prices or technological changes in input-output relationships.

We make two important improvements to the FAOSTAT database: (i) adding additional categories of emissions, and (ii) allocating emissions by commodity across sources of emissions. The two most important categories of emissions to be added are energy use in agriculture and emissions from pesticide use. We also move emissions from burning of savannah grasslands to the land use category, rather than the agricultural emissions category, as much of this burning is unrelated to agricultural production.

Table 2 shows the importance of incorporating different sources of emissions into our analysis. A striking feature of the table is the importance of enteric fermentation in both rich and poor countries. This is primarily from ruminant animals such as cattle and sheep and contributes close to 34 percent of total emissions. Another striking feature is the importance of livestock manure, which contributes 22.5 percent of total emissions. Direct energy use by the sector accounts for 13 percent of total energy use and 16 percent in OECD members. Volatilization of synthetic fertilizers is another important contributor, accounting for 14 percent of total emissions in the OECD member countries and 10 percent in non-OECD members. Rice cultivation accounted for almost 10 percent of total emissions, being much more important in developing countries than in the OECD. Crop residues were the next most important source, accounting for roughly almost five percent of emissions, considering both burning and decomposition of residues, making them similar in importance to emissions resulting from direct energy use by the agricultural sector. 
Table 2. Emissions* from Agriculture by Source, 2013-15 (shares in percent)

\begin{tabular}{l|rrr}
\multicolumn{1}{c}{} & OECD & Non-OECD & World \\
\hline Burning of crop residues & 0.5 & 0.5 & 0.5 \\
Burning of savannah & 3.3 & 4.3 & 4.1 \\
Crop residues & 4.5 & 3.2 & 3.5 \\
Energy use** & 16.4 & 11.8 & 12.9 \\
Enteric fermentation & 31.0 & 34.4 & 33.6 \\
Manure management & 9.2 & 4.6 & 5.7 \\
Manure left on pasture & 10.7 & 14.6 & 13.7 \\
Manure applied to soils & 4.4 & 2.7 & 3.1 \\
Cultivation of organic soils & 2.9 & 1.9 & 2.1 \\
Pesticides & 1.5 & 1.3 & 1.4 \\
Rice Cultivation & 1.7 & 10.7 & 8.6 \\
Synthetic Fertilizers & 14.0 & 10.0 & 10.9 \\
Total & 100.0 & 100.0 & 100.0
\end{tabular}

Source: FAOSTAT. Notes: * Emissions measured in $\mathrm{CO}_{2}$ equivalent. **Data for the latest available year, 2012.

The FAOSTAT database also provides data on emissions by commodity, as presented in Table 3. Production of ruminant meat is by far the most important source of emissions, accounting for 48 percent of total emissions. Milk production is the second most important source, with close to 17 percent of the total. This is broadly consistent with the importance of enteric fermentation and manure in Table 1. Rice is the third most important source of global emissions. This importance of this category is very different between OECD and non-OECD countries, with its share of emissions six times higher in Non-OECD countries than in the OECD.

Table 3. Agricultural Emissions* by Commodity, 2014 (shares in percent)

\begin{tabular}{l|rrr}
\multicolumn{1}{c}{ OECD } & Non-OECD & World \\
\hline Rice & 3.2 & 20.8 & 16.6 \\
Other cereals & 18.4 & 8.5 & 10.9 \\
Milk & 18.3 & 16.8 & 17.1 \\
Ruminant meat & 49.8 & 47.6 & 48.1 \\
Pig meat & 7.0 & 3.4 & 4.3 \\
Poultry meat & 2.1 & 1.7 & 1.8 \\
Eggs & 1.1 & 1.2 & 1.1 \\
Total & 100.0 & 100.0 & 100.0
\end{tabular}

Source: FAOSTAT: Note: * Emissions measured in $\mathrm{CO}_{2}$ equivalent. 
A key influence on the outcome of policy reforms is the relative emission intensity of production in different regions, measured by the $\mathrm{kg}$ of $\mathrm{CO} 2$-equivalent produced per $\mathrm{kg}$ of the product. If support is reduced in an area where the emission intensity is particularly high and replaced by production from another region where the emission intensity is low, this change is likely to contribute to a reduction in total emissions. The emission intensities for key products and regions are presented in Table 4.

Table 4. Emission Intensities for Key Products and Regions, kg $\mathrm{CO}_{2}$ eq./kg of product.

\begin{tabular}{l|rrrrrrr}
\multicolumn{1}{c}{} & $\begin{array}{r}\text { Cereals } \\
\text { excl. rice }\end{array}$ & Eggs & $\begin{array}{r}\text { Bovine } \\
\text { meat }\end{array}$ & Chicken & $\begin{array}{r}\text { Pig } \\
\text { meat }\end{array}$ & Milk & Rice \\
\hline Australia & 0.3 & 0.4 & 20.2 & 0.2 & 2.5 & 0.7 & 0.7 \\
Brazil & 0.2 & 0.8 & 35.7 & 0.3 & 2.6 & 1.2 & 0.5 \\
EU & 0.2 & 0.7 & 15.4 & 0.3 & 1.6 & 0.6 & 3.0 \\
India & 0.3 & 0.5 & 108.3 & 0.5 & 5.0 & 1.1 & 0.7 \\
USA & 0.2 & 0.5 & 12.1 & 0.3 & 2.0 & 0.4 & 1.1 \\
OECD & 0.2 & 0.5 & 15.1 & 0.3 & 1.7 & 0.5 & 1.2 \\
Non-OECD & 0.2 & 0.8 & 32.8 & 0.7 & 1.4 & 1.3 & 0.9 \\
World & 0.2 & 0.7 & 25.4 & 0.6 & 1.5 & 0.9 & 0.9
\end{tabular}

Source: FAOSTAT.

A key feature of Table 4 is the enormous differences in emission intensities across regions and commodities. The emission intensity for bovine meat is by far the largest for any food. And it varies from 12.1 in the United States to 108.3 in India. There is clearly a link between income levels and intensity, with the intensity for beef being more than twice as high in the non-OECD group than in the OECD. However, there are clearly also important idiosyncratic influences on emission intensities - they are, for instance, slightly lower in the EU and the United States than for the OECD as a group. As another example, both Australia and Brazil have emission intensities that are slightly higher than for the OECD and non-OECD averages. The emission intensities for milk look deceptively low but would range from 3.3 to 9.7 if expressed in milk powder equivalent using the standard conversion factor of 7.6 (FAO 2017, p123). The dispersion of intensities is much less than in the case of beef, for which it is quite substantial. Intensities are generally lower in higher-income countries.

A difficulty with the characterization of emissions provided in Tables 2 and 3 is that it does not clarify the source of emissions in the production of each commodity. If, for instance, we 
want to examine the impacts of a fertilizer subsidy, these data — or models based on them — do not allow us to investigate the impacts. Nor do they allow us to investigate the impacts of changes in production technologies that apply to one production activity rather than others - such as use of feed additives designed to reduce GHG emissions - suitable for daily-handled dairy cows but not beef cattle fed on extensive pastures. To deal with this problem, we developed a database of emissions by type and by commodity. We aimed to produce a database of emissions for production, based on FAOSTAT, with the key assumptions used in the carbon footprint of agriculture. The idea is to reverse engineer aggregated emission data to identify individual coefficients that properly traces the drivers of emissions: scale, location, composition and technological choice. In doing so, we followed a bottom-up approach for computing emissions at different stages and carried out quality control at different stages by checking if the numbers add up to the aggregated numbers at the total agriculture level in the FAOSTAT database.

Thus, GHG by source are calculated in three steps, that is, we recalculate first the emission coefficients (EC) for $\mathrm{N}_{2} \mathrm{O}$ and $\mathrm{CH}_{4}$ for each emission source; then we recompute emissions of $\mathrm{N}_{2} \mathrm{O}$ and $\mathrm{CH}_{4}$ for each activity and finally, we recompute the $\mathrm{CO}_{2}$-equivalent from $\mathrm{N}_{2} \mathrm{O}$ and $\mathrm{CH}_{4}$ emissions. ${ }^{3}$ The emission sources used follow FAOSTAT and include: burning crop residues and savanna; emissions from crop residues; manure management, manure applied to cropland manure left on pasture; rice cultivation; cultivation of organic soils; enteric fermentation, energy and synthetic fertilizers. Emissions from energy consumption in agriculture are taken from the FAOSTAT for the year 2012, the latest available year for this series.

The FAOSTAT emission database further provides implied emission factors for various activities by emission source, such as area harvested in rice cultivation and the nitrogen content of manure. The database in some cases provides the base activity data, such as areas of organic soil cultivation; and the number of head of livestock for enteric fermentation and manure management. In other cases, such as biomass burned (dry matter) when burning crop residues, only computed activity data are provided, rather than the underlying data. In such cases, we import base activity data from the FAOSTAT crop and livestock production database. For synthetic nitrogen fertilizer, the activity data (i.e., agriculture use in nutrients) is missing and thus we used the FAO emission numbers instead of recomputing them. For the final version of the

\footnotetext{
${ }^{3}$ We use 310 as the default value for computing the $\mathrm{CO}_{2}$ equivalent of $\mathrm{N}_{2} \mathrm{O}$ and 21 as the $\mathrm{CO}_{2}$ equivalent of $\mathrm{CH}_{4}$.
} 
database created for the present analysis, we keep the base activity data (we call them index data) to get average emission value per index type (land, animals, output, fertilizer and energy).

In the case of enteric fermentation and manure management (during storage and treatment, in application to soils and left on pasture) we disaggregated the livestock numbers for buffaloes, camels, goats and sheep in line with the value of their products- meat, milk and wool (sheep). The resulting livestock numbers were then linked to emissions using data from the FAOSTAT emissions database. In the final step we produced emissions data by country, emission source and sector. The broad structure of the emission shares is presented in Table 5.

Table 5: Shares of Agricultural Emissions by Commodity and Source, 2015 (\% of total)

\begin{tabular}{|c|c|c|c|c|c|c|c|c|}
\hline & Rice & $\begin{array}{l}\text { Other } \\
\text { Cereals }\end{array}$ & Milk & $\begin{array}{c}\text { Ruminant } \\
\text { meat }\end{array}$ & Pig meat & $\begin{array}{c}\text { Poultry } \\
\text { meat }\end{array}$ & Eggs & Total \\
\hline Burning crops & 0.2 & 0.5 & 0.0 & 0.0 & 0.0 & 0.0 & 0.0 & 0.7 \\
\hline Crop residue & 1.3 & 3.1 & 0.0 & 0.0 & 0.0 & 0.0 & 0.0 & 4.4 \\
\hline Enteric fermentation & 0.0 & 0.0 & 11.0 & 30.5 & 0.6 & 0.0 & 0.0 & 42.1 \\
\hline Manure management & 0.0 & 0.0 & 1.6 & 2.4 & 2.8 & 0.4 & 0.3 & 7.5 \\
\hline Manure left on pasture & 0.0 & 0.0 & 3.6 & 13.3 & 0.0 & 0.7 & 0.4 & 18.0 \\
\hline Manure applied to soils & 0.0 & 0.0 & 1.0 & 1.1 & 0.9 & 0.7 & 0.4 & 4.2 \\
\hline Pesticides & 0.2 & 0.8 & 0.0 & 0.1 & 0.0 & 0.0 & 0.0 & 1.1 \\
\hline Rice cultivation & 12.6 & 0.0 & 0.0 & 0.0 & 0.0 & 0.0 & 0.0 & 12.6 \\
\hline Synthetic fertilizers & 2.4 & 6.5 & 0.0 & 0.7 & 0.0 & 0.0 & 0.0 & 9.6 \\
\hline Total & 16.6 & 10.9 & 17.1 & 48.1 & 4.3 & 1.8 & 1.1 & 100.0 \\
\hline
\end{tabular}

Source: Authors' computation. Notes: Results are global averages.

\section{Agricultural Incentives}

Farmers' decisions on production levels and methods of production are influenced by three broad policy interventions:

(i) Coupled and decoupled subsidies,

(ii) Import measures, and

(iii) Export measures

In this section of the study, we discuss the approaches that we used to measure the extent of these interventions. We first consider coupled subsidies, that is payments by government that 
change the net returns farmers receive for their current outputs or pay for their inputs and, hence, create incentives for farmers to change their output levels. We deal with these first, partly because they are expected to have a more adverse impact on emissions from agriculture than import or export measures that contribute to the overall level of measured market price support (MPS). This is because, in contrast with market price support measures such as tariffs, they do not provide incentives for consumers in protecting countries to reduce their consumption of potentially polluting agricultural commodities ${ }^{4}$. There is also a political-economy reason for focus on these subsidies. As they must be financed by governments, they are likely to receive more scrutiny from Ministries of Finance than measures such as tariffs that change producer returns indirectly by raising domestic prices relative to world prices. The export taxes used in some developing countries have a similar feature, with Ministries of Finance often providing support, rather than opposition, for these measures.

\section{Coupled Subsidies}

Data on coupled subsidies paid by government for producers are presented in Table 6 . The purpose of this table is to disaggregate total subsidies into those that influence output (coupled subsidies) and those that do not (decoupled subsidies). Another purpose is to provide estimates of the share of coupled subsidies that are subject to environmental conditionality. A third is to identify those subsidies that support the use of fertilizer. The final column, for GSSE, is provided to allow comparison between subsidies paid directly to farmers and payments made to strengthen the enabling environment for agriculture (see OECD 2018a).

\footnotetext{
${ }^{4}$ Our emphasis on these commodities differs from studies such as Mayrand et al (2003) in which coupled subsidies are classified as most-distorting. While we agree with this assessment for trade impacts, we do not for environmental impacts. Whether trade barriers will raise or lower emissions is an empirical question. If protection is applied mainly to countries with little comparative advantage, where production at world prices is far below consumption, the reduction in demand may exceed the reduction in supply. Whether this is the case also depends on the elasticities of supply and demand.
} 
Table 6. Annual coupled subsidies and GSSE paid by governments, 2014-16 (US\$ billion)

\begin{tabular}{|c|c|c|c|c|c|c|}
\hline & Narrow & Broader & & All & & \\
\hline & Environmental & Environmental & Fertilizer & Coupled & Decoupled & GSSE \\
\hline & Conditionality & Conditionality & Subsidies & Subsidies & Subsidies & \\
\hline Australia & 0.2 & 0.1 & 0.0 & 0.5 & 0.4 & 1.0 \\
\hline Brazil & 0.0 & 2.9 & 0.0 & 4.5 & 0.0 & 2.7 \\
\hline Canada & 0.0 & 0.0 & 0.0 & 1.7 & 0.0 & 1.8 \\
\hline Switzerland & 0.8 & 2.6 & 0.0 & 1.4 & 1.1 & 0.8 \\
\hline Chile & 0.0 & 0.1 & 0.0 & 0.4 & 0.0 & 0.4 \\
\hline China & 0.0 & 7.2 & 0.0 & 53.7 & 5.9 & 39.9 \\
\hline Colombia & 0.0 & 0.0 & 0.0 & 0.9 & 0.0 & 0.6 \\
\hline Costa Rica & 0.0 & 0.0 & 0.0 & 0.0 & 0.0 & 0.0 \\
\hline EU28 & 8.8 & 65.0 & 0.0 & 36.2 & 44.4 & 12.9 \\
\hline Indonesia & 0.0 & 0.0 & 1.4 & 1.9 & 0.0 & 1.2 \\
\hline India & 0.0 & 0.0 & 11.0 & 28.0 & 0.0 & 12.2 \\
\hline Iceland & 0.0 & 0.0 & 0.0 & 0.1 & 0.0 & 0.0 \\
\hline Israel & 0.0 & 0.0 & 0.0 & 0.2 & 0.0 & 0.2 \\
\hline Japan & 2.4 & 5.8 & 0.0 & 4.8 & 3.0 & 8.4 \\
\hline Kazakhstan & 0.0 & 0.0 & 0.0 & 1.1 & 0.0 & 0.5 \\
\hline Korea & 0.8 & 0.9 & 0.1 & 1.0 & 0.8 & 2.9 \\
\hline Mexico & 1.1 & 1.1 & 0.0 & 3.7 & 0.0 & 0.8 \\
\hline Norway & 0.1 & 0.1 & 0.0 & 1.4 & 0.0 & 0.2 \\
\hline New Zealand & 0.0 & 0.0 & 0.0 & 0.0 & 0.0 & 0.4 \\
\hline Philippines & 0.0 & 0.0 & 0.0 & 0.0 & 0.0 & 0.0 \\
\hline Russia & 0.0 & 0.0 & 0.0 & 0.0 & 0.0 & 0.0 \\
\hline Turkey & 0.1 & 0.1 & 0.3 & 3.1 & 0.0 & 2.9 \\
\hline Ukraine & 0.0 & 0.0 & 0.0 & 1.1 & 0.0 & 0.2 \\
\hline USA & 5.1 & 24.9 & 0.0 & 16.8 & 11.2 & 8.7 \\
\hline Vietnam & 0.0 & 0.0 & 0.0 & 0.5 & 0.0 & 0.7 \\
\hline South Africa & 0.0 & 0.0 & 0.0 & 0.2 & 0.0 & 0.3 \\
\hline Total & 19.4 & 110.8 & 12.8 & 163.3 & 66.8 & 99.7 \\
\hline
\end{tabular}

Source: OECD (2018a). Note: Narrow environmental conditionality is based on OECD flags for environmental conditions on input use. Broader conditionality measures include conditions such as cross-compliance requirements in the EU. Coupled subsidies include payments based on outputs, payments based on inputs and payments based on activity levels such as area or livestock numbers. Decoupled subsidies are measures intended to avoid creating incentives to change output, specifically categories E (production not required); F (Payments based on non-commodity criteria) and G (miscellaneous payments) of the OECD (2016, p23). GSSE measures are payments designed to influence the environment for agriculture without payments directly to farmers. For consistency, we use the OECD measure that fertilizer subsidies are zero in China, although some other sources identify these subsidies to fertilizer-producing enterprises as being a subsidy to farmers (Huang, Gulati and Gregory 2017).

The first column of the table shows the value of subsidies provided subject to environmental conditions on input use, as designated by the OECD. This was only US $\$ 19.4$ billion of total subsidies of US $\$ 163$ billion. Using a broader measure of environmental conditionality that 
includes broader requirements such as cross-compliance conditions in the EU and the USA results in US\$110 billion of support subject to some form of conditionality, over 80 percent of which was in the US and the EU. This suggests that the coverage of conditionality is substantial, only the effectiveness of this conditionality remains a source of uncertainty.

This broader measure of conditionality was created by expert reviews ${ }^{5}$ of the extent of environmental conditionality in policies and countries covered by the OECD's Monitoring and Outlook Studies (2018a). It includes all measures where the OECD "cookbook" providing descriptions of policies, or the analyst's familiarity with the country's policies, indicated that support under that policy is subject to environmental conditionality. The results in the table make clear that most of this support is provided by the EU, with the United States as the second-most important provider of this type of support. As we considered quite general conditionality schemes such as the EU's "cross-compliance" conditions (OECD 2018b), the resulting US\$148 billion in support subject to environmental conditions is much larger than the $\$ 19$ billion indicated by OECD as being subject to input conditionality for environmental purposes.

Fertilizer subsidies amount to around US $\$ 13$ billion per year in the table with 85 percent of the subsidies included in the countries covered by the OECD accounted for by India and most of the remainder by Indonesia. Expanding the sample to countries not covered by the OECD would likely increase the importance of this measure, although it seems unlikely that it would become greatly more important as a share of overall agricultural support.

The total amount of coupled subsidies in Column 4 of Table 6 is heavily influenced by support to farmers in China and India, because a large amount of this type of support has been transferred to decoupled form in the US and the EU (see Mamun, Martin, and Tokgoz 2019). There is some controversy about the extent to which subsidies provided to Chinese agriculture are, in fact, coupled with output at the producer level as many were originally introduced in ways that appeared to be lump sum in nature (Huang et al. 2011). In India, as we will see, positive support from coupled subsidies operates in an environment where output prices have been depressed by border policies.

The final column of Table 6 shows that governments also spent substantial amounts on support designed to improve the enabling environment for agriculture, such as investments in

\footnotetext{
${ }^{5}$ The team undertook these reviews for all 26 economies covered by the OECD Monitoring and Outlook dataset. Team members were Lars Brink, Joe Glauber, Will Martin, Valeria Pineiro and Simla Tokgoz.
} 
agricultural research and development and rural infrastructure. Many of these investments, and particularly investments in agricultural research and development, appear to have high rates of return (Alston et al. 2009, Zhang and Fan 2004, Fan, Cho and Rue 2018, Laborde et al. 2019), probably because governments under-invest in these activities. By contrast, much of the benefit to society of coupled subsidies is lost through costly increases in production. While the measures reported under GSSE clearly influence output levels and emission levels, they largely do so by overcoming market failures, such as under-investment by private agents in research and development and/or provision of infrastructure. While their impact on output is generally very substantial, their impact on producer returns and on emissions is ambiguous, depending on factors such as the impact on output prices and output levels.

\section{Import Measures}

While the goal of the Uruguay Round of WTO negotiations was to convert all agricultural trade measures affecting imports into tariffs (Hathaway and Ingco 1995), many different—and frequently non-transparent--agricultural trade measures remain, including the Tariff Rate Quotas introduced during those negotiations. This greatly complicates the challenge of estimating agricultural protection. Furthermore, successive rounds of preferential trade negotiations have resulted in very substantial differences between the tariffs levied on different suppliers (Guimbard et al. 2012).

Unfortunately, a key result of this is that standard tariff measures provide little guidance on the rate of protection to agriculture or to individual agricultural commodities. Another challenge for measuring agricultural protection is the presence of trade measures on exports. Of these, export taxes or export restrictions designed to lower domestic prices are the most common, although export subsidies designed to raise domestic prices have been widely used in agriculture in the past.

The primary approach that economists have followed to deal with these problems is to estimate the average rate of protection or taxation by comparing the domestic price of a good with the price of a comparable traded good, with both prices adjusted for any transportation or marketing costs between the points at which they are observed (OECD 2016). While this approach is suitable for measuring the average rate of protection for agriculture, it does not allow 
us to account for the presence of trade flows subject to protection rates that differ from the average - such as those within free trade areas or customs unions. To deal with this problem, we have combined data from the OECD database on agricultural support measures with data on preferential tariff rates obtained from the GTAP v10 database (see Aguiar et al (2016) for the broad structure of this database).

For consistency with the approach used in modeling trade flows in IFPRI's global computable general equilibrium model, MIRAGRODEP, applied in this study, we use the OECD measures of agricultural trade distortions to indicate the protection rate applying on nonpreferential trade flows, and then scale down protection on preferential trade flows (Hoekman, Martin and Braga 2009) in line with the tariffs on those flows ${ }^{6}$. This results in a database on protection that captures these two key dimensions of global agricultural protection. Data from this database for import protection in broad groups of countries and for select individual countries are given in Table 7.

\footnotetext{
${ }^{6}$ More specifically, we use the ratio of the power of the tariff on import of the good from country $\mathrm{i},\left(1+\mathrm{t}_{\mathrm{i}}\right)$, to the power of the tariff from country $\mathrm{j}$.
} 
Table 7. Agricultural Import Protection in Covered Countries, \%

\begin{tabular}{|c|c|c|c|c|c|c|c|c|}
\hline & Farm & Milk & Beef & Pork/Poultry & Rice & Sugar & Veg/Fruits & Wheat \\
\hline World & 16.3 & 26.2 & 17.8 & 19.8 & 27.5 & 26.5 & 8.3 & 7.3 \\
\hline Developed & 18.9 & 39.5 & 23.0 & 29.3 & 39.0 & 20.6 & 8.8 & 2.9 \\
\hline Developing & 14.7 & 21.7 & 13.5 & 12.4 & 25.1 & 29.3 & 7.6 & 8.0 \\
\hline Australia & 0.0 & & & & & & 0.1 & \\
\hline Brazil & 4.4 & 4.5 & 0.3 & & 17.9 & 0.0 & 4.4 & 5.9 \\
\hline Canada & 3.7 & 76.3 & 1.6 & 4.7 & & 0.2 & & \\
\hline Chile & 0.5 & & & & 1.8 & 3.5 & & \\
\hline China & 23.4 & 60.0 & 15.4 & 13.6 & 45.2 & 71.2 & 9.8 & 52.5 \\
\hline Colombia & 25.7 & 30.5 & 4.1 & 27.8 & 170.6 & 34.6 & 1.6 & 9.8 \\
\hline Costa Rica & 17.3 & 6.7 & 0.0 & 74.6 & 152.8 & 36.2 & & \\
\hline EFTA & 33.0 & 39.9 & 73.1 & 103.7 & 8.2 & 18.9 & 7.5 & 46.7 \\
\hline EU28 & 6.8 & 0.6 & 34.3 & 4.9 & 16.4 & 15.3 & 7.9 & 2.1 \\
\hline Indonesia & 18.8 & 4.8 & 30.7 & 53.8 & 73.4 & 69.8 & & 2.4 \\
\hline India & 20.5 & 21.5 & 8.5 & 2.1 & 6.0 & 7.1 & 21.7 & 18.9 \\
\hline Israel & 14.6 & 53.2 & 22.4 & 12.8 & & & 2.1 & 11.5 \\
\hline Japan & 41.6 & 107.2 & 38.5 & 52.0 & 220.5 & 35.1 & 50.9 & \\
\hline Kazakhstan & 6.2 & 0.9 & 19.2 & 18.9 & 1.1 & 24.7 & 1.7 & 0.1 \\
\hline Rep Korea & 108.1 & 129.6 & 47.0 & 92.3 & 119.2 & 7.0 & 81.8 & 1.2 \\
\hline Mexico & 2.4 & 4.7 & & 4.4 & 5.4 & 14.8 & 0.8 & \\
\hline New Zealand & 0.8 & & & 3.3 & & 2.1 & & \\
\hline Philippines & 27.5 & 1.1 & 10.0 & 32.2 & 140.8 & 37.8 & & 2.7 \\
\hline Russia & 12.9 & 20.9 & 32.5 & 15.3 & 7.3 & 33.8 & 2.4 & 0.2 \\
\hline Turkey & 19.9 & 4.2 & 144.9 & 38.8 & & 19.2 & 14.1 & 10.7 \\
\hline Ukraine & 4.5 & 7.3 & 2.0 & 10.4 & 4.7 & 44.0 & 0.8 & 5.4 \\
\hline USA & 2.3 & 13.3 & 2.0 & 0.1 & & 32.0 & 0.2 & \\
\hline Vietnam & 21.0 & 4.0 & 54.2 & 6.0 & 0.4 & 75.8 & 4.1 & 2.6 \\
\hline \multicolumn{9}{|l|}{ Regional aggregates } \\
\hline Asia & 14.0 & 23.9 & 8.7 & 5.0 & 6.9 & 64.3 & 5.9 & 3.4 \\
\hline Central America & 28.6 & 61.1 & 6.3 & 52.2 & 31.9 & 7.9 & 9.6 & 0.0 \\
\hline Former Soviet U & 5.6 & 6.4 & 7.7 & 9.1 & 3.8 & 3.5 & 6.4 & 0.5 \\
\hline Latin America & 5.1 & 4.6 & 1.8 & 10.0 & 4.1 & 21.8 & 1.4 & 7.1 \\
\hline Middle E \& N Africa & 6.0 & 4.2 & 3.7 & 6.8 & 9.9 & 4.8 & 4.4 & 10.2 \\
\hline Sub-Saharan Africa & 14.2 & 9.0 & 7.7 & 13.6 & 28.3 & 15.8 & 6.7 & 7.2 \\
\hline South Africa & 5.5 & 6.4 & & 0.1 & & 36.5 & & 5.2 \\
\hline
\end{tabular}

Source: Authors' computations based on OECD data. Note: Most blank cells refer to zero protection while a few refer to minor products not covered by the OECD database.

The pattern of import protection observed in Table 7 has potentially important implications for emissions. Of the commodities with the largest emission intensities—beef, milk and rice-milk and rice have particularly high average rates of protection. Average protection rates are 
substantially lower on beef, at around 18 percent, but this rate of protection is vastly higher than for lightly protected, low-emission, commodities such as vegetables and fruit, and wheat. On average, protection rates for all the high-emission commodities are much higher in rich countries than in developing countries. Rates of protection for these commodities vary considerably between countries, with rates over 100 percent for rice in traditional high-protection countries such as Japan and the Republic of Korea, but also in developing countries such as Colombia and the Philippines. Rates of protection to beef are high in traditional high-protection economies such as the EU28, Japan and Korea, but also in Indonesia, Russia and Vietnam.

\section{Export Measures}

In many countries, protection or taxation is observed for exported commodities. This implies the existence of export taxes when domestic prices are artificially depressed and export subsidies when domestic prices are increased by the intervention. In these cases, we used the price gap estimated by the OECD (2018a) to create a measure of the implicit export tax or subsidy applying to those trade flows. Results for these trade flows are given in Table 8. 
Table 8. Export taxes and/or subsidies, \%

\begin{tabular}{|c|c|c|c|c|c|c|c|c|}
\hline & Farm & Milk & Beef & Pork/Poultry & Rice & Sugar & Veg/Fruits & Wheat \\
\hline World & 2.6 & 0.6 & 3.8 & 0.0 & 8.9 & -0.5 & 1.4 & 3.7 \\
\hline Developed & 0.2 & -0.2 & & & & & & 1.1 \\
\hline Developing & 4.6 & 2.9 & 8.7 & 0.1 & 10.0 & -0.6 & 1.9 & 16.8 \\
\hline Canada & -0.2 & -22.0 & & & & & & \\
\hline EFTA & -1.4 & -2.4 & 0.0 & -0.4 & & & & \\
\hline Indonesia & 0.2 & 9.1 & & & & & & \\
\hline India & 15.3 & 25.1 & 37.3 & & 11.1 & -19.8 & 33.6 & 21.1 \\
\hline Israel & 0.1 & & & & & & -0.2 & \\
\hline Kazakhstan & 7.4 & & & & 40.9 & & & 2.4 \\
\hline Philippines & 0.0 & & & & & & & \\
\hline Russia & 6.6 & & & & & & & 6.9 \\
\hline Ukraine & 17.5 & 24.4 & & & & & & 25.9 \\
\hline Vietnam & 14.2 & & & 2.1 & & & 22.6 & \\
\hline \multicolumn{9}{|l|}{ Regional aggregates } \\
\hline Asia & 4.4 & & & 0.3 & 15.0 & & & \\
\hline Central America & 0.5 & & 5.8 & & & & & \\
\hline Latin America & 11.9 & 4.5 & 1.5 & & & & & 25.3 \\
\hline$M E \& N$ Africa & 0.0 & & & & & & 0.0 & \\
\hline Sub-Saharan Africa & 5.6 & 13.9 & 10.4 & & & 8.5 & & \\
\hline
\end{tabular}

Source: Authors' Calculations. Note: Most blank cells imply zero export tax rates. A few may refer to cases where the product was regarded as too minor to include in the OECD estimates of agricultural support. Either way, the blank cells can be ignored without great cost to the accuracy of the overall assessment.

The export tax/subsidy measures presented in Table 8 are, on average, substantially lower than the import measures in Table 7. However, they are nontrivial for several commodities and countries. On average, they are largest for India and for Ukraine, countries where policy appears to have reduced food prices to consumers at the expense of farm returns. India's policies appear to have imposed implicit export taxes on a wide range of commodities - including dairy, beef, oilseeds, vegetables and fruit, rice and wheat. By commodity, export taxes are largest for rice, with sizeable implicit export taxes in two major exporters-India and Kazakhstan. They are also sizeable for oilseeds in many countries, sometimes because of a desire to subsidize oilseed crushing at the expense of oilseed producers. 
The two components of all the support that influences output decisions are coupled subsidies and market price support. Coupled subsidies generally tend to increase output without lowering demand in the affected countries, while market price support increases demand in protecting regions but, at the same time, reduces demand for agricultural products by raising prices to consumers. A rough indicator of the magnitude of each of these supports is provided by dividing the value of producer support provided by the value of output at world prices.

Table 9. Coupled Subsidies vs Market Price Support, 2014-16 (\%)

\begin{tabular}{|c|c|c|}
\hline & Coupled Subsidies & Price Support \\
\hline Australia & 1.1 & 0.0 \\
\hline Brazil & 2.9 & 1.1 \\
\hline Canada & 4.0 & 6.2 \\
\hline Switzerland & 26.2 & 68.6 \\
\hline Chile & 3.0 & 0.1 \\
\hline China & 4.4 & 12.7 \\
\hline Colombia & 4.0 & 14.8 \\
\hline Costa Rica & 0.0 & 10.8 \\
\hline EU28 & 8.6 & 4.9 \\
\hline Indonesia & 2.0 & 33.2 \\
\hline India & 6.8 & -13.2 \\
\hline Iceland & 38.0 & 67.0 \\
\hline Israel & 3.3 & 15.1 \\
\hline Japan & 10.7 & 71.9 \\
\hline Kazakhstan & 9.0 & -1.9 \\
\hline Korea & 4.8 & 88.8 \\
\hline Mexico & 7.0 & 2.1 \\
\hline Norway & 61.8 & 68.0 \\
\hline New Zealand & 0.1 & 0.6 \\
\hline Philippines & 0.0 & 31.0 \\
\hline Russia & - & 10.1 \\
\hline Turkey & 6.4 & 29.5 \\
\hline Ukraine & 3.5 & -11.5 \\
\hline USA & 4.6 & 2.8 \\
\hline Vietnam & 1.3 & -3.7 \\
\hline South Africa & 1.2 & 2.1 \\
\hline Total & 5.1 & 7.9 \\
\hline
\end{tabular}

Source: OECD (2018a). Note: Both forms of support are expressed as a share of value of production at world prices. 
A surprising feature of Table 9 is the relatively small gap between the average rate of support provided by coupled subsidies of 5.1 percent and the average support provided by market price support (MPS) of 7.9 percent. This is partly because MPS includes both positive support from tariffs and negative support from direct or implicit export taxes. While the combination of positive and negative support contributes to higher economic costs from MPS measures than from subsidies (Anderson, Martin and Valenzuela 2006), it results in a lower average rate of support from border measures than would otherwise be the case.

An interesting feature of the table is the high rates of the protection in some cases, with countries like Iceland, Norway and Switzerland, having much higher than average rates of both coupled subsidies and border support. A second interesting feature is the combination of positive protection from coupled subsidies and negative protection from border measures in countries like India, Kazakhstan, Ukraine and Vietnam. These countries typically are net exporters-or potential net exporters - of certain key commodities and apparently choose to use export barriers to lower the cost of food to domestic consumers.

\section{Analyzing the Impacts of Agricultural Support}

To assess the impacts of current agricultural support, we examine the implications of moving from current support levels to a hypothetical situation in the absence of any global intervention. For this analysis, we use IFPRI's MIRAGRODEP model (Laborde, Robichaud and Tokgoz 2013), which is an extension of the widely used MIRAGE model of the global economy (Decreux and Valin 2007). The underlying database used for the analysis is Prerelease 3 of the GTAP v10 database for 2014. The data on agricultural support were adjusted in line with the measures discussed in Section 3 for agricultural border measures and subsidies that influence output or input decisions (coupled subsidies). The model was augmented with a post-solution model based on the estimates discussed in Section 2 linking GHG emissions to output and inputs of agricultural activities determined in the model. The combined model was then used to assess the impacts of policy reform on emissions of $\mathrm{CO}_{2}, \mathrm{CH}_{4}$ and $\mathrm{N}_{2} \mathrm{O}$, and these results combined to generate a total $\mathrm{CO}_{2}$ equivalent.

The macroeconomic assumptions used for the analysis were designed to be relatively "neutral" to avoid situations where macroeconomic adjustments such as real exchange rate 
changes outweigh the impacts of interest, and to allow us to focus on the impacts of agricultural support policies on emissions. These assumptions were:

(i) Static version of the model

(ii) Public purchases held constant and a variable consumption tax used to hold the deficit to GDP ratio constant,

(iii) Land use held constant to focus on emissions from agriculture

(iv) A constant level of employment.

Our approach of holding land use constant is consistent with the study by Henderson and Lankoski (2019) for the OECD and allows us to focus on changes in agricultural emissions, without needing to address the impacts of land use change, which are very context specific. In this paper, we begin by considering the impact of removing coupled subsidies, and then turn to border measures.

\section{Implications of Coupled Subsidies}

To understand the impacts of current subsidies, we consider in Table 10 the percentage changes in key farm outputs from removal of coupled subsidies. Removal of these subsidies causes a reduction in overall farm output of close to one percent, with a reduction of 1.7 percent in developed countries and a much smaller reduction in developing countries. The smaller reduction in developing country output reflects the much smaller use of subsidies in poorer developing countries (Anderson, Martin and Valenzuela 2006), and perhaps also the limited coverage of developing country assistance in the OECD database on which we relied in preparing this study. 
Table 10. Percentage Changes in Output following Removal of Coupled Subsidies, \%

\begin{tabular}{|c|c|c|c|c|c|}
\hline & Farm & Beef & Dairy & Rice & Pork/Poultry \\
\hline World & -0.9 & -0.7 & -0.6 & -0.9 & -0.6 \\
\hline Developed & -1.7 & -1.1 & -1.3 & -0.3 & -1.2 \\
\hline Developing & -0.5 & -0.2 & 0.3 & -1.0 & -0.3 \\
\hline Australia & 1.7 & 1.4 & 1.1 & 1.0 & 0.5 \\
\hline Brazil & 0.3 & 0.4 & 0.0 & -1.5 & 1.1 \\
\hline Canada & 1.7 & 1.7 & 0.2 & 0.3 & 1.7 \\
\hline Chile & -1.0 & -0.1 & -0.1 & 0.4 & -0.6 \\
\hline China & -1.1 & -0.1 & 0.1 & -1.6 & -0.4 \\
\hline Colombia & 0.5 & -0.1 & -0.1 & -0.1 & -0.1 \\
\hline Costa Rica & 0.5 & 0.0 & 0.3 & 0.4 & 0.0 \\
\hline EFTA & -6.7 & -8.9 & -4.9 & -5.3 & -7.3 \\
\hline EU28 & -3.4 & -3.5 & -1.5 & -1.4 & -2.5 \\
\hline Indonesia & -0.3 & -0.3 & 0.6 & -0.4 & 0.1 \\
\hline India & -1.7 & -2.1 & 0.2 & -2.9 & -1.2 \\
\hline Israel & 0.4 & -0.6 & -0.1 & 1.4 & -0.5 \\
\hline Japan & -2.9 & -3.2 & -3.8 & -0.4 & -0.3 \\
\hline Kazakhstan & -0.8 & -1.3 & -0.1 & 0.1 & -1.7 \\
\hline Rep Korea & 0.0 & 0.1 & 0.5 & -0.3 & 0.1 \\
\hline Mexico & -3.3 & -7.0 & 0.0 & 1.0 & -4.2 \\
\hline New Zealand & 1.3 & 2.4 & 0.9 & 0.9 & 2.0 \\
\hline Philippines & 0.2 & 0.5 & 0.5 & 0.0 & 0.1 \\
\hline Russia & -1.6 & -0.5 & -3.5 & -0.8 & -2.3 \\
\hline Turkey & -3.9 & -2.2 & 0.9 & 2.7 & 0.8 \\
\hline Ukraine & 0.4 & -2.5 & 0.2 & 1.0 & -1.3 \\
\hline USA & 0.0 & 0.1 & -0.2 & 1.0 & 0.7 \\
\hline Vietnam & 0.2 & 0.7 & 0.2 & 0.2 & -0.2 \\
\hline \multicolumn{6}{|l|}{ Regional averages } \\
\hline Asia & 0.4 & 0.5 & 0.4 & 0.3 & 0.5 \\
\hline Central America & 0.4 & 0.3 & 0.4 & 0.1 & 0.1 \\
\hline Former Soviet U & 0.6 & 0.1 & 1.1 & 0.2 & 0.3 \\
\hline Latin America & 0.5 & 0.3 & 0.2 & 0.4 & 0.0 \\
\hline Middle East \& N Africa & 0.7 & 0.8 & 0.3 & 0.9 & 0.1 \\
\hline Sub Saharan Africa & 0.3 & 0.0 & 0.4 & 0.1 & 0.2 \\
\hline South Africa & 1.0 & 0.2 & 0.4 & 0.0 & 0.8 \\
\hline
\end{tabular}

Source: Authors' model results.

The implications of removing coupled subsidies for overall emissions are given in Table 11. This table shows a reduction of 34 million tons of $\mathrm{CO}_{2}$ equivalent, or around -0.6 percent, resulting 
from removal of these subsidies. Interesting, the largest single component of this reduction arises from cuts in the use of synthetic fertilizer, with reductions in emissions from enteric fermentation the second largest component. The economies that reduce their emissions the most tend to be countries like China, the EU and Mexico that currently provide substantial subsidies to agriculture. By contrast, countries providing relatively low subsidies, like Australia, see an increase in emissions as they attempt to take advantage of higher world prices resulting from removal of subsidies elsewhere and increase their output. 
Table 11. Impacts on Emissions of Abolishing Coupled Subsidies, kt of $\mathrm{CO}_{2}$ equivalent ${ }^{\mathrm{a}}$

\begin{tabular}{|c|c|c|c|c|c|c|}
\hline & All & Crop Residues & $\begin{array}{c}\text { Enteric } \\
\text { Fermentation }\end{array}$ & Manure & Rice & $\begin{array}{l}\text { Synthetic } \\
\text { Fertilizer }\end{array}$ \\
\hline World & -34420 & -2915 & -6016 & -3871 & -1041 & -10138 \\
\hline Developed & -18116 & -1079 & -4107 & -2987 & -206 & -4942 \\
\hline Developing & -16304 & -1836 & -1909 & -884 & -834 & -5197 \\
\hline Australia & 1880 & 99 & 711 & 497 & -1 & 280 \\
\hline Brazil & 967 & -62 & 886 & 538 & -9 & -337 \\
\hline Canada & 1669 & 295 & 236 & 195 & 0 & 593 \\
\hline Chile & -40 & 0 & -9 & -18 & 0 & 2 \\
\hline China & -6011 & -792 & -45 & -294 & -459 & -1758 \\
\hline Colombia & 43 & 0 & -15 & -7 & -3 & 11 \\
\hline Costa Rica & 12 & 0 & 3 & 1 & 0 & 5 \\
\hline EFTA & -1009 & -15 & -369 & -258 & 0 & -112 \\
\hline EU28 & -17141 & -1278 & -4177 & -3304 & 20 & -4162 \\
\hline Indonesia & -4 & -32 & -35 & -7 & -13 & 51 \\
\hline India & -10459 & -1032 & -1989 & -764 & -266 & -3085 \\
\hline Israel & 12 & 1 & -2 & -3 & 0 & 5 \\
\hline Japan & -1296 & -99 & -147 & -85 & -229 & -305 \\
\hline Kazakhstan & -237 & -11 & -88 & -63 & -28 & -6 \\
\hline Rep Korea & 29 & -1 & 6 & 5 & 0 & -1 \\
\hline Mexico & -5640 & -139 & -2886 & -1613 & 1 & -317 \\
\hline New Zealand & 692 & 2 & 350 & 249 & 0 & 63 \\
\hline Philippines & 55 & 3 & 28 & 20 & -9 & 9 \\
\hline Russia & -2428 & -10 & -725 & -491 & 0 & -687 \\
\hline Turkey & -1927 & -248 & -114 & -88 & -2 & -901 \\
\hline Ukraine & 282 & 108 & -60 & -70 & 0 & 203 \\
\hline USA & -514 & -72 & 8 & 204 & 4 & -611 \\
\hline Vietnam & 118 & 8 & 51 & 18 & -4 & 34 \\
\hline \multicolumn{7}{|l|}{ Regional aggregates } \\
\hline Asia & 1540 & 60 & 718 & 412 & -27 & 263 \\
\hline Central America & 185 & 1 & 94 & 45 & -2 & 23 \\
\hline Former Soviet $U$ & 749 & 22 & 266 & 163 & -1 & 142 \\
\hline Latin America & 1123 & 136 & 468 & 207 & -6 & 94 \\
\hline Middle East \& N Africa & 1616 & 112 & 291 & 232 & 1 & 237 \\
\hline Sub Saharan Africa & 992 & 6 & 484 & 366 & -7 & 91 \\
\hline South Africa & 321 & 23 & 42 & 43 & 0 & 37 \\
\hline
\end{tabular}

Source: Authors' computations based on MIRAGRODEP simulation results. Note: a. Total GHG emissions in "kt of CO2 equivalent" are composed of $\mathrm{CO}_{2}$ totals excluding short-cycle biomass burning (such as agricultural waste burning and Savannah burning) but including other biomass burning (such as forest fires, post-burn decay, peat fires and decay of drained peatlands), all anthropogenic $\mathrm{CH}_{4}$ sources, $\mathrm{N}_{2} \mathrm{O}$ sources and F-gases (HFCs, PFCs and SF6). Note: $\mathrm{kt}=$ thousand tonnes. 
Our first experiment in this section considers elimination of all agricultural border measures, both import and export. We first consider the impact on agricultural output levels by commodity, and then the impact on overall greenhouse gas emissions expressed in $\mathrm{CO}_{2}$ equivalents. We then turn to the impacts on agricultural emissions. Table 12 presents the effects on output for agriculture overall and for key emission-intensive commodities. 
Table 12. Output Changes from Abolition of all Border Measures, \%

\begin{tabular}{|c|c|c|c|c|c|}
\hline & Farm & Beef & Dairy & Rice & Pork/Poultry \\
\hline World & -0.1 & -0.2 & -0.9 & -0.4 & 0.3 \\
\hline Developed & -0.6 & -3.0 & 1.4 & -3.3 & -1.3 \\
\hline Developing & 0.1 & 2.7 & -3.5 & -0.2 & 1.3 \\
\hline Australia & 20.9 & 31.2 & 40.2 & 22.3 & 2.7 \\
\hline Brazil & 11.1 & 18.1 & -1.1 & -2.9 & 19.4 \\
\hline Canada & -2.8 & 8.3 & -46.6 & 0.1 & 13.2 \\
\hline Chile & 5.6 & 9.9 & 10.1 & 0.8 & 8.9 \\
\hline China & -3.6 & -3.6 & -39.6 & -1.1 & -0.1 \\
\hline Colombia & -2.2 & 1.6 & -8.4 & -43.8 & -1.4 \\
\hline Costa Rica & -0.5 & 4.4 & -2.8 & -49.6 & -22.1 \\
\hline EFTA & -22.0 & -36.5 & -17.5 & 47.5 & -39.8 \\
\hline EU28 & -1.3 & -12.8 & 7.1 & -20.1 & -2.1 \\
\hline Indonesia & -5.2 & -24.2 & -0.8 & -9.0 & -5.0 \\
\hline India & 2.4 & 32.0 & 3.5 & 6.2 & 0.7 \\
\hline Israel & -6.0 & -20.5 & -19.2 & 106.9 & -6.5 \\
\hline Japan & -21.8 & -32.6 & -64.7 & -4.4 & -22.7 \\
\hline Kazakhstan & -0.1 & -2.5 & -1.2 & 23.6 & -15.7 \\
\hline Rep Korea & -10.8 & -18.3 & -47.7 & -13.4 & -6.6 \\
\hline Mexico & -2.2 & 5.0 & -1.7 & -2.4 & -10.3 \\
\hline New Zealand & 25.5 & 46.5 & 26.3 & -33.2 & -15.8 \\
\hline Philippines & -5.0 & -12.0 & 67.3 & -27.4 & -5.7 \\
\hline Russia & -8.8 & -11.7 & -14.1 & -11.5 & -10.6 \\
\hline Turkey & -14.9 & -67.2 & 5.6 & 5.9 & -11.8 \\
\hline Ukraine & 16.9 & 40.7 & 21.7 & -28.5 & 2.6 \\
\hline$U S A$ & 4.9 & 3.8 & 8.7 & 29.6 & 4.8 \\
\hline Vietnam & 5.0 & -42.4 & 27.9 & 10.3 & -2.2 \\
\hline Asia & 3.5 & -5.1 & 1.3 & 4.0 & 16.2 \\
\hline Central America & 3.3 & 0.8 & 5.8 & 1.9 & 0.1 \\
\hline Former Soviet $U$ & 2.2 & 16.7 & -1.0 & -4.9 & -4.2 \\
\hline Latin America & 5.2 & 18.9 & 5.6 & 1.0 & 1.5 \\
\hline Middle East \& N Africa & -0.2 & -6.0 & 1.4 & -4.2 & 0.4 \\
\hline Sub Saharan Africa & 0.1 & -0.6 & 0.5 & -0.9 & -0.1 \\
\hline South Africa & 1.5 & 0.2 & 2.7 & 5.0 & 1.0 \\
\hline
\end{tabular}

Source: Authors' computations based on MIRAGRODEP simulation results. Note: Result are presented for overall farm output and selected commodities. Border measures include import tariffs, export taxes and nontariff measures applied at the border.

Clearly output levels are likely to decline in initially protected regions and increase in regions that were originally lightly protected, not protected, or subject to taxation. If emission intensities 
were the same in all regions, the only thing that would matter for global GHG emissions is the impact of reform on global output. However, we know that emission intensities for agricultural products are frequently, but not always, much lower in the rich countries than in poor countries (Mamun, Martin and Tokgoz 2019), so we also need to examine changes in output by country.

A key result in Table 12 is that global farm output declines by 0.1 percent with removal of all agricultural trade distortions. This result is consistent with protection expanding agricultural output slightly, by pulling additional non-land resources into the sector, while resources are moved out of the sector in non-distorting countries because of lower world prices. The effect is much smaller than for coupled subsidies, despite the greater magnitude of market price support. This might, at first, seem surprising but reflects the fact that protection reduces consumption in the imposing countries, as well as increasing output in those regions. The effect on global output is an empirical question, with the answer depending heavily on the importance of the protecting countries as consumers relative to their importance as producers. As noted in the introduction, if countries imposing protection were almost completely dependent on imports for their consumption, the effect on world output would be much the same as with a consumption tax in those regions. Given that most of the high protection is in net importing countries, it is perhaps not surprising that the impact of removing border measures is close to zero.

Another potentially important change in output patterns is reductions in output of most of the emission-intensive goods in the relatively low-emission-intensity high-income countries, while output expands in developing countries. A broadly similar pattern is seen for beef, rice and pork/poultry. Milk is slightly different, with a modest overall expansion in developed countries outweighing a small average decline in output in developing countries. The combination of the expansion in overall farm output with the larger expansion of beef and milk production look likely to be important influences on overall GHG emissions.

Looking at the country-level changes, the results for overall farm output follow an expected pattern, with reductions in farm output in highly protected economies such as Japan and Korea and increases in lightly protected economies such as Australia, Brazil, New Zealand and the Ukraine. For the individual emission-intensive commodities, there are important changes, such as a 32 percent increase in production of beef (including buffalo meat) in India and large increases in output of key products in both Australia and New Zealand. By contrast, output of all these products falls in Japan and Korea as expected. There are also considerable variations in 
outcomes by product within countries, with Canada seeing a modest increase in beef production, a large increase in pork and poultry production and a decline of almost 50 percent in dairy production.

In terms of overall national income and overall farm income, the changes from elimination of all agricultural border measures reflect the overall impact of distortions on individual sectors, as seen in Table 13. For the world overall, both national income and farmer income increase. Real national income rises in all regions with reductions in inefficiency outweighing terms of trade deteriorations in importing countries. Producers in the most protected economies, such as Japan, Korea and the EFTA countries, suffer quite strong losses of farm income, while competitive exporters such as Australia, Brazil, Canada, New Zealand and the United States experience sizeable gains in real farm incomes. For most other countries, the changes in national farm income are relatively small, suggesting that — where they arose — the biggest political challenges would likely involve balancing between gainers and losers, such as dairy farmers and other producers in Canada. 
Table 13. Changes in Real National Income and Farm Income, all border measures, \%

\begin{tabular}{|c|c|c|}
\hline & Real Income & Real Farmer Income \\
\hline World & 0.3 & 0.9 \\
\hline Developed & 0.3 & 0.9 \\
\hline Developing & 0.4 & 0.9 \\
\hline Australia & 0.4 & 16.8 \\
\hline Brazil & 0.4 & 6.6 \\
\hline Canada & 0.3 & 2.4 \\
\hline Chile & 0.0 & 3.5 \\
\hline China & 0.6 & -2.5 \\
\hline Colombia & 0.5 & 0.7 \\
\hline Costa Rica & 1.4 & 6.1 \\
\hline EFTA & 0.6 & -16.4 \\
\hline EU28 & 0.1 & -0.1 \\
\hline Indonesia & 0.5 & -1.7 \\
\hline India & 0.0 & 3.5 \\
\hline Israel & 0.4 & -4.9 \\
\hline Japan & 0.6 & -14.8 \\
\hline Kazakhstan & 0.2 & 4.1 \\
\hline Rep Korea & 3.2 & -19.4 \\
\hline Mexico & 0.2 & -0.2 \\
\hline New Zealand & 2.5 & 25.6 \\
\hline Philippines & 1.2 & -4.9 \\
\hline Russia & 0.3 & -0.4 \\
\hline Turkey & 1.0 & -3.8 \\
\hline Ukraine & 1.2 & 33.9 \\
\hline USA & 0.0 & 5.5 \\
\hline Vietnam & 2.8 & 23.8 \\
\hline Asia & 0.2 & 3.8 \\
\hline Central America & 0.1 & 3.5 \\
\hline Former Soviet U & 0.3 & 3.4 \\
\hline Latin America & 0.3 & 6.0 \\
\hline Middle East \& N Africa & 0.1 & 0.2 \\
\hline Sub-Saharan Africa & 0.1 & 0.4 \\
\hline South Africa & 0.2 & 2.9 \\
\hline
\end{tabular}

Source: Authors' computations based on MIRAGRODEP simulation results. Note: border measures include price-based measures such as tariffs, export taxes, import subsidies, and nontariff measures that change the price of domestic goods relative to world prices.

The impacts of abolishing border measures on emissions are given in detail in Table 14. The table shows an overall increase in global GHG emissions of 128 million tons of $\mathrm{CO}_{2}$ 
equivalent, or 2.1 percent, with a 1.9 percent increase in developed countries and a 2.2 percent increase in developing countries. This increase in emissions is despite the decline in global output seen in Table 10 and indicates that simple abolition of current border measures would increase emissions by changing the composition and location of output in ways that lead to increased emissions. 
Table 14. Impacts on Emissions of Abolishing Border Distortions, kt of $\mathrm{CO}_{2}$ equivalent

\begin{tabular}{|c|c|c|c|c|c|c|}
\hline & & Crop & Enteric & & & Synthetic \\
\hline & Total & Residues & Fermentation & Manure & Rice & Fertilizer \\
\hline World & 127635 & 4129 & 91043 & 39624 & -1193 & 1203 \\
\hline Developed & 25597 & 3115 & 11644 & 9139 & 201 & 3042 \\
\hline Developing & 102037 & 1013 & 79399 & 30486 & -1394 & -1839 \\
\hline Australia & 26913 & 223 & 14756 & 9995 & 5 & 683 \\
\hline Brazil & 66288 & 1174 & 40800 & 20208 & -60 & 1688 \\
\hline Canada & 838 & 62 & -91 & 357 & 0 & 380 \\
\hline Chile & 857 & 1 & 438 & 377 & 0 & 14 \\
\hline China & -51961 & -3029 & -17404 & -9390 & 197 & -9002 \\
\hline Colombia & -1448 & -111 & -494 & -203 & -179 & -311 \\
\hline Costa Rica & -8 & -6 & -8 & -45 & -3 & 19 \\
\hline EFTA & -3391 & -46 & -1299 & -978 & 0 & -283 \\
\hline$E U 28$ & -17619 & -570 & -7612 & -5016 & -150 & -2788 \\
\hline Indonesia & -7669 & -460 & -3256 & -2131 & -673 & -1047 \\
\hline India & 61442 & 1639 & 38188 & 13270 & 600 & 4706 \\
\hline Israel & -229 & -4 & -79 & -87 & 0 & -4 \\
\hline Japan & -5188 & -18 & -1883 & -1529 & 78 & -43 \\
\hline Kazakhstan & 129 & 255 & -192 & -163 & 8 & 152 \\
\hline Rep Korea & -2421 & -58 & -707 & -496 & -36 & -224 \\
\hline Mexico & 2071 & -26 & 1941 & 316 & 0 & -73 \\
\hline New Zealand & 13700 & 2 & 7121 & 4834 & 0 & 1189 \\
\hline Philippines & -4124 & -447 & -712 & -575 & -1760 & -679 \\
\hline Russia & -6838 & 1580 & -4461 & -2858 & -25 & 1092 \\
\hline Turkey & -11865 & -291 & -4940 & -4426 & 12 & -773 \\
\hline Ukraine & 9120 & 1941 & 2141 & 1083 & -5 & 2284 \\
\hline$U S A$ & 19603 & 1941 & 5819 & 4829 & 329 & 3036 \\
\hline Vietnam & -4432 & 211 & -3211 & -1901 & 169 & 299 \\
\hline Asia & -93 & 360 & -3108 & 1090 & 430 & 255 \\
\hline Central America & 1008 & 12 & 533 & 227 & -2 & 132 \\
\hline Former Soviet $U$ & 8587 & 47 & 4687 & 3054 & -11 & 331 \\
\hline Latin America & 37646 & -200 & 26226 & 11477 & -43 & -42 \\
\hline Middle East \& N Africa & -2615 & -77 & -1384 & -1058 & -36 & -75 \\
\hline Sub-Saharan Africa & -1412 & -47 & -831 & -698 & -39 & 136 \\
\hline South Africa & 745 & 72 & 65 & 61 & 0 & 149 \\
\hline
\end{tabular}

Notes: Only key sources are included, with smaller items such as Pesticides and Direct Energy use included in the total, but not presented separately. Crop Residues and Burning Crop residues have been combined to save space, as have Manure Management, Manure on Pastures and Manure on soils. Source: Authors' calculations. 
The table shows that around 90 percent of the increase in emissions came from two sources of livestock-related emissions-Enteric Fermentation and Manure. These increases in emissions are heavily concentrated in Australia, Brazil, India, the United States and other Latin America, where output of livestock products is expected to increase. The increases in emissions from these two categories in Brazil and India reflect the increases in beef (including buffalo) output reported in Table 12. These increases are so large that they explain almost all the increase from developing countries, and almost all the global increase in emissions. These increases in beef output have two quite different sources. The increase from Brazil reflects the limited protection provided to livestock products in Brazil and the expansion of this sector in response to greater market opportunities created by the abolition of import barriers. The increase from India reflects the abolition of export barriers reported in Table 6. Emission reductions are projected for China, the EU, Russia and Turkey, where reductions in livestock production are predicted.

\section{Abolition of Border Measures and Coupled Subsidies}

The effects of abolition of both border measures and coupled subsidies on output of key agricultural commodities are shown in Table 15. The broad pattern is close to the sum of the two components, with modest declines in overall output, and substantial reallocations of production from currently-protected countries to those that are unprotected, or even taxed, rather than one of uniform shifts between developed and developing countries. Thus, output of beef increases substantially in Australia, Brazil, Canada, Colombia, India, New Zealand and Ukraine while falling sharply in Europe and Japan. 
Table 15. Output Changes from Abolition of all Border Measures \& Coupled Subsidies, \%

\begin{tabular}{|c|c|c|c|c|c|}
\hline & Farm & Beef & Dairy & Rice & Pork/Poultry \\
\hline World & -1.1 & -0.8 & -1.4 & -1.4 & -0.3 \\
\hline Developed & -2.4 & -4.2 & 0.0 & -3.4 & -2.6 \\
\hline Developing & -0.4 & 2.8 & -3.0 & -1.2 & 1.2 \\
\hline OECD Sample & -2.1 & -2.5 & -2.3 & -3.0 & -1.2 \\
\hline Australia & 23.2 & 33.3 & 42.8 & 24.2 & 3.2 \\
\hline Brazil & 11.7 & 19.8 & -1.1 & -4.5 & 21.3 \\
\hline Canada & -1.0 & 10.5 & -46.2 & 0.5 & 15.6 \\
\hline Chile & 4.7 & 10.6 & 10.2 & 1.4 & 8.1 \\
\hline China & -4.7 & -3.5 & -39.2 & -2.9 & -0.5 \\
\hline Colombia & -1.7 & 1.6 & -8.2 & -43.9 & -1.5 \\
\hline Costa Rica & 0.0 & 4.7 & -2.5 & -48.6 & -22.1 \\
\hline EFTA & -30.0 & -45.9 & -24.9 & 41.9 & -46.1 \\
\hline EU28 & -5.1 & -17.2 & 5.2 & -20.8 & -5.0 \\
\hline Indonesia & -5.5 & -24.4 & 0.0 & -9.4 & -4.9 \\
\hline India & 1.0 & 29.6 & 3.8 & 2.9 & -0.6 \\
\hline Israel & -5.3 & -20.9 & -18.1 & 112.0 & -7.5 \\
\hline Japan & -24.5 & -35.2 & -67.4 & -4.8 & -22.6 \\
\hline Kazakhstan & -0.8 & -3.7 & -1.3 & 24.8 & -18.0 \\
\hline Rep. Korea & -10.5 & -17.9 & -46.6 & -13.4 & -6.2 \\
\hline Mexico & -5.7 & -2.6 & -1.6 & -1.3 & -14.9 \\
\hline New Zealand & 27.3 & 51.3 & 27.2 & -33.0 & -15.4 \\
\hline Philippines & -4.3 & -10.8 & 75.0 & -27.2 & -5.5 \\
\hline Russia & -10.4 & -12.1 & -18.0 & -11.9 & -13.1 \\
\hline Turkey & -18.9 & -69.4 & 7.7 & 9.5 & -10.2 \\
\hline Ukraine & 16.7 & 32.3 & 22.2 & -27.0 & 0.4 \\
\hline USA & 5.1 & 3.9 & 8.7 & 31.0 & 5.6 \\
\hline Vietnam & 5.3 & -41.8 & 28.6 & 10.6 & -2.3 \\
\hline Asia & 4.1 & -4.6 & 1.8 & 4.5 & 17.6 \\
\hline Central America & 3.8 & 1.1 & 6.4 & 2.0 & 0.2 \\
\hline Former Soviet Union & 2.8 & 17.4 & 0.0 & -4.8 & -4.1 \\
\hline Latin America & 5.9 & 20.1 & 6.2 & 1.4 & 1.6 \\
\hline Middle East \& N Africa & 0.5 & -5.0 & 1.7 & -3.0 & 0.5 \\
\hline Sub-Saharan Africa & 0.4 & -0.6 & 0.8 & -0.6 & 0.0 \\
\hline South Africa & 2.5 & 0.4 & 3.4 & 4.9 & 1.7 \\
\hline
\end{tabular}

Source: Authors' computations based on MIRAGRODEP simulation results. 
Results for the impact on emissions of the abolition of border measures and coupled subsidies are presented in Table 16. These results reveal that the effects of abolishing market access barriers and coupled subsidies are somewhat different from the sum of their separate effects. The result of these two reforms is an increase in emissions of 102 million tons of $\mathrm{CO}_{2}$ equivalent or 1.7 percent of the base level. Much of the increase is associated with the increases in output of bovine meat in Brazil and India. 
Table 16. Impacts on Emissions of Abolishing Coupled Subsidies \& Border Distortions, kt of $\mathrm{CO}_{2}$ equivalent

\begin{tabular}{|c|c|c|c|c|c|c|}
\hline & & Crop & Enteric & & & Synthetic \\
\hline & Total & Residues & Fermentation & Manure & Rice & Fertilizer \\
\hline World & 102071 & 1257 & 88780 & 37691 & -2331 & -7511 \\
\hline Developed & 7590 & 1728 & 7529 & 6086 & -33 & -1811 \\
\hline Developing & 94481 & -471 & 81251 & 31605 & -2298 & -5700 \\
\hline Australia & 28986 & 282 & 15683 & 10636 & 5 & 884 \\
\hline Brazil & 71705 & 1207 & 44319 & 21961 & -72 & 1651 \\
\hline Canada & 2168 & 249 & 208 & 618 & 0 & 744 \\
\hline Chile & 837 & 0 & 449 & 364 & 0 & 14 \\
\hline China & -58045 & -3870 & -17224 & -9508 & -329 & -10944 \\
\hline Colombia & -1381 & -111 & -483 & -200 & -181 & -305 \\
\hline Costa Rica & 5 & -6 & -3 & -43 & -3 & 23 \\
\hline EFTA & -4146 & -57 & -1571 & -1169 & 0 & -370 \\
\hline$E U 28$ & -36517 & -1814 & -12817 & -9064 & -140 & -6948 \\
\hline Indonesia & -7644 & -492 & -3270 & -2118 & -676 & -1008 \\
\hline India & 52513 & 777 & 35948 & 12410 & 236 & 2366 \\
\hline Israel & -212 & -3 & -79 & -88 & 0 & 0 \\
\hline Japan & -5353 & -16 & -1858 & -1505 & -171 & -28 \\
\hline Kazakhstan & -103 & 241 & -280 & -225 & -17 & 133 \\
\hline Rep Korea & -2359 & -59 & -693 & -481 & -36 & -223 \\
\hline Mexico & -4039 & -160 & -1239 & -1456 & 0 & -381 \\
\hline New Zealand & 14796 & 3 & 7673 & 5218 & 0 & 1307 \\
\hline Philippines & -3978 & -441 & -647 & -532 & -1756 & -668 \\
\hline Russia & -8786 & 1460 & -4926 & -3244 & -25 & 526 \\
\hline Turkey & -12220 & -308 & -5158 & -4606 & 5 & -789 \\
\hline Ukraine & 9092 & 2011 & 1950 & 987 & -5 & 2429 \\
\hline$U S A$ & 18800 & 1680 & 5830 & 5079 & 333 & 2298 \\
\hline Vietnam & -4307 & 223 & -3166 & -1881 & 179 & 328 \\
\hline Asia & 1663 & 421 & -2304 & 1703 & 444 & 399 \\
\hline Central America & 1232 & 13 & 660 & 288 & -3 & 149 \\
\hline Former Soviet $U$ & 9488 & 66 & 5092 & 3319 & -12 & 421 \\
\hline Latin America & 40510 & -94 & 27978 & 12246 & -47 & 18 \\
\hline$M$ East \& N Africa & -1192 & 1 & -1046 & -784 & -30 & 99 \\
\hline Sub-Saharan Africa & -473 & -36 & -354 & -334 & -32 & 185 \\
\hline South Africa & 1030 & 90 & 107 & 102 & 0 & 179 \\
\hline
\end{tabular}

Source: Authors' computations based on MIRAGRODEP simulation results 
As was the case with the removal of market access distortions, the largest influence on the outcome is an increase in emissions from enteric fermentation and from livestock manure. The biggest contribution comes again from increased emissions in Brazil and India, along with smaller increases in countries such as Australia, New Zealand and the United States. The result is ameliorated to a modest degree by reductions in emissions from synthetic fertilizers and rice production, primarily in developing countries.

The finding that overall abolition of subsidies and border protection increases emissions is somewhat surprising and potentially controversial. In general, there is no strong reason to expect that measures introduced primarily for political-economy reasons unrelated to climate change mitigation would have either a positive or negative impact on GHG emissions. One might expect that abolition of such measures might — by increasing overall economic efficiency - reduce emissions to the extent that it leads to the adoption of lower-cost, and generally more efficient, approaches to production.

However, as noted in Mamun, Martin and Tokgoz (2019), agricultural protection tends to be higher in developed countries, where emission intensities tend to be lower than in developing countries. Abolition of protection, by unwinding the tendency to relocate production in the highincome countries, may well result in an increase in emissions of the type observed in our model results. While the results are much more specific than this, with sharp differences in emission intensities within both the rich and the poor country group, this difference is probably a major contributing factor to the findings from our model-based analysis.

Our results are also influenced by our decision to fix land use in agriculture in all countries so that we could focus on the impacts of reform on agricultural emissions without, because of time constraints, being able to address the issue of land use change. While solving the problem of dealing with land use increases in developing countries, it reduces the ability of our modelling to consider reductions in land use in the countries that currently provide the highest rates of support to agriculture. Taking land use changes into account is an important priority for further work in this area. This will be particularly important both for assessing the full impacts of subsidy reform on emissions, and for assessing the impacts of productivity changes that can raise agricultural yields and lead to sustainable intensification of agriculture that allow for sizeable reductions in the agricultural land use footprint. 
Two simulations were performed for this assessment of the implications of removing farm support and compensating those who lost from this change. The first replicated the results for full liberalization presented in the previous section, with lump sum subsidies or taxes used to maintain farm incomes at their initial level. The second involves the use of output subsidies or taxes set in such a way as to maintain farm incomes. The first simulation produced results very similar to those presented in Tables 14 and 15. In fact, these results were so similar that it makes no sense to present them again. Although the simulation using uniform taxes/transfers to maintain farm incomes at their initial levels is quite hypothetical, it produced results that are quite informative about channels of effect.

The impacts of this reform on outputs of key commodities are shown in Table 17. This experiment involves uniform subsidies to maintain farm incomes in countries where rates of protection were initially high, and uniform taxes in countries where protection was initially low. Relative to Table 15, where existing support is removed without compensation to those producers who lose, or taxation of the gainers, it results in higher farm output overall and in developed countries, but generally lower output in developing countries. In lightly protected countries such as Australia and Brazil, it results in much smaller rises in farm output than under the overall liberalization scenario, where higher world prices shift production to these countries. Economies like Canada and Japan, with wide variations in agricultural support rates, see sharp declines in output from highly supported activities such as dairy production. 
Table 17. Output impacts of removing all support with uniform transfers to maintain farm incomes, $\%$

\begin{tabular}{|c|c|c|c|c|c|}
\hline & Farm & Beef & Dairy & Rice & Pork/Poultry \\
\hline World & 0.7 & 0.3 & 0.8 & 2.7 & 0.9 \\
\hline Developed & 2.0 & -1.1 & 4.9 & 2.7 & 8.0 \\
\hline Developing & 0.0 & 1.8 & -3.9 & 2.6 & 0.2 \\
\hline Australia & 0.8 & 1.9 & 7.9 & -9.6 & 3.2 \\
\hline Brazil & 0.0 & 3.9 & -6.8 & 1.2 & -9.5 \\
\hline Canada & -3.8 & 7.1 & -48.3 & 7.3 & 0.1 \\
\hline Chile & 1.8 & 8.8 & 6.4 & 2.5 & 0.4 \\
\hline China & -0.5 & 1.5 & -31.2 & 4.3 & 2.6 \\
\hline Colombia & -2.4 & 1.6 & -8.9 & -1.7 & -44.2 \\
\hline Costa Rica & -4.7 & -1.7 & -9.8 & -27.5 & -55.6 \\
\hline EFTA & 24.8 & -6.3 & 45.1 & 16.9 & 375.0 \\
\hline EU28 & 2.0 & -8.5 & 14.4 & 1.4 & -10.6 \\
\hline Indonesia & -5.7 & -23.0 & -3.1 & -5.9 & -9.4 \\
\hline India & 0.2 & 28.1 & 3.0 & -0.9 & 1.6 \\
\hline Israel & -2.1 & -9.9 & -22.9 & -4.4 & 215.6 \\
\hline Japan & 2.5 & 19.2 & -35.2 & 21.3 & 13.0 \\
\hline Kazakhstan & -2.5 & -4.8 & -2.5 & -19.7 & 19.8 \\
\hline Rep. Korea & 15.0 & 8.3 & -21.3 & 17.7 & -7.0 \\
\hline Mexico & -1.4 & 5.2 & 2.1 & -8.7 & 4.7 \\
\hline New Zealand & -1.4 & 24.6 & -9.5 & -24.3 & -48.4 \\
\hline Philippines & -0.5 & -4.1 & 65.0 & -1.1 & -19.7 \\
\hline Russia & -7.8 & -7.4 & -18.3 & -10.6 & -9.6 \\
\hline Turkey & -5.2 & -55.5 & 17.3 & 21.3 & 41.0 \\
\hline Ukraine & -8.2 & -12.7 & -16.7 & -33.4 & -53.5 \\
\hline USA & 3.0 & 2.4 & 4.4 & 2.9 & 28.1 \\
\hline Vietnam & -5.6 & -50.4 & -19.3 & -10.5 & -3.2 \\
\hline Asia & 3.0 & -4.6 & 0.1 & 12.4 & 4.1 \\
\hline Central America & 3.1 & 1.1 & 3.4 & -0.3 & 2.1 \\
\hline Former Soviet Union & 1.8 & 15.5 & -2.4 & -5.9 & -5.4 \\
\hline Latin America & 5.3 & 19.3 & 4.2 & 0.9 & 2.1 \\
\hline M East \& N Africa & -0.4 & -5.3 & -0.8 & -1.2 & -2.8 \\
\hline Sub-Saharan Africa & 0.2 & -0.6 & -1.5 & -0.7 & -0.5 \\
\hline South Africa & -2.0 & -2.0 & -2.2 & -3.0 & -6.8 \\
\hline
\end{tabular}

Source: Author's computations based on MIRAGRODEP simulation results.

The changes in emissions associated with this reform are presented in Table 18. The increase in emissions resulting from the abolition of all support is cut in half from the levels reported in Table 16, despite the overall increase in global farm output. As is evident in Table 18, the major source of this change is reductions from the earlier increases in emissions from Enteric 
Fermentation and Manure, particularly in Australia and Brazil, both of which saw large increases in output and emissions from beef under the full liberalization scenario.

Table 18 Impacts on Emissions of Removing all Support with Compensation, kt of $\mathrm{CO}_{2}$ eq.

\begin{tabular}{|c|c|c|c|c|c|c|}
\hline & All & Crop Residues & Enteric Ferm & Manure & Rice & Synth Fert \\
\hline World & 56232 & 1642 & 47711 & 19126 & -2267 & -5965 \\
\hline Developed & 10968 & 2664 & 2530 & 3671 & -14 & -512 \\
\hline Developing & 45264 & -1022 & 45181 & 15455 & -2252 & -5453 \\
\hline Australia & -260 & -54 & 51 & -266 & 3 & -86 \\
\hline Brazil & 8823 & 226 & 6395 & 2987 & -45 & -404 \\
\hline Canada & 767 & 258 & -309 & -14 & 0 & 742 \\
\hline Chile & 516 & -3 & 334 & 199 & 0 & 0 \\
\hline China & -25295 & -1888 & -8295 & -847 & -17 & -6312 \\
\hline Colombia & -1542 & -112 & -534 & -223 & -180 & -347 \\
\hline Costa Rica & -213 & -8 & -131 & -105 & -3 & 14 \\
\hline EFTA & 1605 & -26 & 790 & 558 & 0 & -210 \\
\hline EU28 & -2412 & -760 & 1246 & 1391 & -110 & -3415 \\
\hline Indonesia & -9302 & -682 & -4094 & -3069 & -1054 & -212 \\
\hline India & 49470 & 524 & 35304 & 12225 & 325 & 816 \\
\hline Israel & -67 & 0 & -42 & -50 & 0 & 14 \\
\hline Japan & 611 & 4 & 196 & 652 & -165 & -105 \\
\hline Kazakhstan & -421 & 184 & -389 & -299 & -18 & 113 \\
\hline Rep Korea & 3170 & -34 & 219 & 416 & -32 & -155 \\
\hline Mexico & 2147 & -104 & 2198 & 529 & 1 & -195 \\
\hline New Zealand & 2805 & -5 & 1318 & 824 & 0 & 633 \\
\hline Philippines & -2469 & -306 & -251 & -177 & -1363 & -475 \\
\hline Russia & -7308 & 1648 & -4391 & -2744 & -23 & 522 \\
\hline Turkey & -6283 & -239 & -2962 & -2264 & 24 & -914 \\
\hline Ukraine & -104 & 1398 & -1281 & -1578 & -7 & 1465 \\
\hline USA & 11990 & 1631 & 3411 & 2854 & 313 & 1561 \\
\hline Vietnam & -8332 & -237 & -4139 & -2922 & -245 & -459 \\
\hline Asia & -1719 & 343 & -3949 & 74 & 429 & 447 \\
\hline Central America & 926 & 14 & 469 & 193 & -1 & 142 \\
\hline Former Soviet U & 7480 & 62 & 3975 & 2562 & -12 & 454 \\
\hline Latin America & 38994 & -194 & 27084 & 11827 & -28 & 33 \\
\hline M East \& N Africa & -2727 & -27 & -1672 & -1393 & -27 & 50 \\
\hline Sub-Saharan Africa & -4389 & -34 & -2608 & -1998 & -30 & 197 \\
\hline South Africa & -229 & 59 & -233 & -216 & 0 & 120 \\
\hline
\end{tabular}

Source: Author's computations based on MIRAGRODEP simulation results. 
A striking feature of the emission intensity data provided through FAOSTAT is that the average emission intensity of livestock products is generally much lower in OECD countries than in NonOECD countries (Mamun, Martin and Tokgoz 2019; Tubiello 2012). This suggests that higher productivity tends to lower the emission intensity of agriculture. One potentially important approach to reducing emissions from agriculture is through investments designed to increase productivity and reduce greenhouse gas emissions from agriculture. Investments in agricultural R\&D that raise agricultural productivity also have the key advantage of being a powerful instrument for poverty reduction (Ivanic and Martin 2018).

Clearly, there are many ways in which agricultural emissions per unit of output might be reduced. If, for instance, emissions were linked to the amount of land used, and output per unit of land increased, then emissions per unit of output would decline. Alternatively, an efficiency improvement that reduced the amount of inputs such as feed needed per unit of output would result in a decline in emissions per unit of output where emissions are linked to the feed input.

Gerber et al (2013, pp 48-50) provide a range of alternatives for lowering emissions from livestock, involving a range of strategies such as using feed additives, manipulating rumen behavior, reducing storage time for manure, selecting genetically improved animals and increasing livestock fertility rates. Some of these options (such as increasing fertility) both reduce emissions and increase productivity, while others (such as feed additives designed purely to reduce emissions (e.g., Mernit 2018)) may have little or no impact on productivity. Some options, such as improving calving rates for beef cows and the time required to reach slaughter weight can have large impacts on productivity because of the substantial feed requirements for maintenance in beef cattle.

A similar range of strategies can be envisaged for crop production. For rice, Neue (1993) identifies a range of strategies for reducing emission intensities. Millar et al (2014) identify a similar range of strategies for reducing $\mathrm{N}_{2} \mathrm{O}$ emissions from other cereal crops, using approaches such as selecting the right application rate, using the right fertilizer formulation, and optimizing the timing and placement of fertilizers.

Considerable care needs to be taken in specifying the nature of productivity change when examining its impact on GHG emissions. If emissions are linked to input-use - which is likely for important emission categories such as enteric fermentation in cattle - then widely-used 
approaches to specifying productivity growth such as purely factor-augmenting technical change will not capture such reductions in input intensity. What is needed to capture this is a form of productivity gain that saves on both factors and intermediate inputs. Productivity changes of this broad type are well known in the literature (OECD 2001). While such productivity changes need special weights when index approaches are being used to measure implications for national productivity, this problem does not arise when model-based approaches are being used.

As it would be impossible to analyze all possible forms of productivity change that might apply, we consider two relevant polar cases:

(i) Productivity change that saves all factors and intermediate inputs, and

(ii) Productivity change that reduces emissions without substantially increasing productivity.

The first type of productivity change will reduce emission intensities roughly in proportion to the increase in productivity. Its effect on overall emissions is, however, likely to be influenced by the so-called rebound effect, where the reduction in the cost of the good resulting from the productivity increase raises demand for the good and hence reduces the benefit in terms of emission reduction. Freire-Gonzalez and Puig-Ventosa (2015) examine the importance of this phenomenon and advocate combining productivity change and energy taxes to minimize it. The second type of policy preserves the gains from reductions in emission intensity but faces the risk that it will not be sufficiently attractive to producers for it to be widely adopted. The two cases can perhaps be most usefully thought of as limiting cases that bound a wide range of intermediate possibilities.

For this section, we considered (i) a productivity change that reduced emissions by 30 percent without reducing intermediate or factor input demands, and (ii) a productivity change (MFP) that reduced both the factor and intermediate input demands for all agricultural sectors by 30 percent. The 30 percent was chosen for illustrative purposes because it is widely regarded as being in the order of magnitude of gains feasible in important areas such as reducing generation of greenhouse gases by enteric fermentation (Mernit 2018). The results for percentage reductions in protection from these simulations are presented in Table 19. 
Table 19. Reductions in $\mathrm{CO}_{2}$ Equivalent Emissions from Agriculture, \%

\begin{tabular}{|c|c|c|}
\hline & $\begin{array}{l}\text { Pure Emission- } \\
\text { Reducing }\end{array}$ & $\begin{array}{c}\text { Factor and Input } \\
\text { Saving }\end{array}$ \\
\hline World & -19.5 & -9.5 \\
\hline Developed & -27.7 & -11.2 \\
\hline Developing & -17.1 & -8.9 \\
\hline OECD Sample & -28.8 & -8.6 \\
\hline
\end{tabular}

Source: Author's computations based on MIRAGRODEP simulation results.

The results in the first column of Table 19 reflect the pure emission reductions, not associated with any other increase in productivity. For the set of countries covered by the OECD analysis and, for comparability, by our productivity simulations, the reduction in emissions from agriculture is 28.8 percent, very close to the 30 percent reduction in the emission intensity of each activity. The small discrepancy reflects the presence of some emissions that are linked to the use of peat land, without being linked to agricultural output. The reduction in emissions for Developed Countries is almost as large as for the OECD sample, at 27.7 percent, reflecting (slightly) incomplete coverage of developed countries by the OECD. Globally, emissions are reduced by 19.5 percent, rather than 30 percent, primarily because of the incomplete coverage of world agriculture by the OECD sample.

The second column refers to the case where emission intensities of each activity are also reduced by 30 percent, but these reductions are accompanied by savings of factors and intermediate inputs. In this situation, there are two determinants of emission outcomes-the reduction in emissions associated directly with the reduction in the emission intensity of each activity, and the increase in output associated with the famous "rebound" or Jevons effect associated with the increase in productivity. This effect seemed surprisingly large given the relatively low elasticities of demand for agricultural products in the model, so we investigated the changes in output by sector associated with it. The associated changes in output are given in Table 20. The large changes in output occurred despite large falls in world prices of agricultural products (22.5 percent on average across all farm products) that were needed to offset the large increase in the effective price of agricultural products associated with the increase in productivity (see Martin and Alston 1997). 
Table 20. Percentage Changes in Output by Sector and Region, 30\% MFP increase

\begin{tabular}{l|rrrr}
\multicolumn{1}{c}{} & World & Developed & Developing & OECD Sample \\
\hline Dairy & 17.4 & 26.7 & 7.8 & 28.4 \\
Fibers & 23.0 & 49.2 & 18.3 & 39.4 \\
Maize & 8.0 & 7.8 & 8.1 & 13.6 \\
Beef & 15.4 & 22.0 & 9.3 & 23.9 \\
Pork \& Poultry & 22.7 & 25.4 & 21.0 & 29.5 \\
Other Crops & 12.7 & 22.7 & 7.2 & 23.2 \\
Rice & 15.4 & 21.1 & 14.8 & 26.9 \\
Wheat & 9.8 & 24.1 & 2.3 & 23.0 \\
All Crops & 14.0 & 21.7 & 11.9 & 24.5 \\
All Farm & 16.4 & 23.9 & 12.8 & 26.3 \\
All Livestock & 19.0 & 24.9 & 14.1 & 27.8
\end{tabular}

Source: Author's computations based on MIRAGRODEP simulation results.

The OECD sample column is easiest to interpret because our productivity simulation affects all the countries included in it. The overall increase in farm output is strikingly large given the 30 percent cost reduction and the relatively low elasticities of demand for most agricultural products. One cause of this large increase in output is the increase in the efficiency of grain production, which - in addition to the increase in productivity within the livestock sectorincreases the supply of livestock products. Another cause is the double impact of productivity change on output - a 30 percent increase in productivity increases output for unchanged inputs by 30 percent and increases the incentive to use additional inputs in this activity (Martin and Alston 1997). At the same time, however, the increase in the efficiency of feed use in the livestock sector reduces the demand for feed from maize and similar commodities, which end up expanding less than other crop and livestock activities. This result illustrates the complexity of productivity increases of this type - that save both inputs and factors - because of their compounding effect along value chains.

Another striking feature of the table is the very large increases in output of agricultural fibers. This reflects the competition between agricultural fibers such as cotton and synthetic fibers in the production of textiles. There are also important, but relatively smaller, differences in output effects between crops and livestock. Livestock output rises somewhat more, partly because the elasticity of demand for livestock products is larger, and partly because of the increase in the productivity of the feed-producing sector. Despite the larger increase in output 
from the relatively emission-intensive livestock sector, agricultural emissions fall by 9.6 percent because of the large savings in emissions within these sectors.

The very large reductions in emissions associated with pure emission-reducing innovations (see Table 15) relative to those associated with productivity-enhancing innovations that only incidentally reduce emissions have important policy implications. While raising productivity in ways that reduces input use can lower emissions, it is clear from this analysis that the rebound effect of this type of productivity increase is quite large. This suggests that research that focusses primarily on emission reduction could be quite important in achieving overall reductions in emissions. This result may change to some degree once the analysis can be extended to include changes in land use change. If land-saving technology enables reductions in the global agricultural footprint, it may be able to harvest gains from carbon sequestration that are in addition to those included here - although the extent of these gains will depend on the types of land that leave agricultural use.

\section{Conclusions}

The analysis presented in this paper examines the implications of current levels of support to farmers on global agricultural emissions. To assess this impact, we examined the impact of eliminating the current measures. In this initial assessment, we focused only on emissions from agricultural production, and constrained land use to remain constant. We built on the OECD (2018a) measures of agricultural incentives, and developed a new model relating emissions to agricultural outcomes that accounts for the specificity of emissions by production sector and by source of emissions.

Our analysis leads to the conclusion that subsidies coupled to production result in increases in global agricultural output and emissions. Eliminating these measures resulted in a decline in global farm output volume of 0.9 percent, with slightly smaller declines in the output of some of the most emission-intensive commodities, such as beef ( -0.7 percent) and dairy products (-0.6 percent). The decline in the $\mathrm{CO}_{2}$ equivalent of global emissions from agriculture was 0.6 percent, partly because of the smaller declines in output of the most emission-intensive products and partly because the relocation of production in some cases resulted in increases in the emission intensity of production. 
When coupled subsidies and border measures are eliminated, we see a decline in global farm output, largely in the developed countries. Despite this decline in output, global emissions rose because of the movement from relatively low-emission-intensity countries to somewhat higher emission intensity countries such as Brazil. However, the increase in emissions is smaller than when only border measures are abolished, because of the elimination of the stimulus to output of emission-intensive activities from coupled subsidies.

We also investigated the effects of investments that increase agricultural productivity or reduce emissions from agricultural production. A key feature of the productivity-increasing simulations is that they involve saving of intermediate inputs as well as factors, since pure factoraugmenting technological change would not generally reduce emission intensities. The productivity-increasing technological changes were compared with experiments in which the emission-intensities of products were reduced by the same 30 percent without increases in productivity. The pure reductions in emission intensities generated much greater reductions in emissions from agriculture that were roughly three times as large as those from the productivityincreasing simulations because the productivity increases generated a substantial rebound effect with especially large increases in output in livestock sectors.

This work has many limitations and its results need to be interpreted with considerable caution. Given the time constraint under which this report was prepared, we were forced to rely almost entirely on the measures of agricultural support provided by the OECD. While these measures cover a very large share of global output, they omit some important agricultural producers such as Argentina and many developing countries whose collective output is considerable. Extending the coverage of these measures is an important priority for future research. Another important priority for the future is to comprehensively consider the impacts of reforming agricultural incentives on land use change and particularly the substantial emissions associated with deforestation. Finally, our tentative conclusion that simply reducing current agricultural distortions has a relatively limited impact on emissions - and may even increase them-points to a need to investigate the use of the multiple instruments needed to achieve policy makers' multiple goals. 


\section{References}

Aguiar, Angel, Badri Narayanan, \& Robert McDougall. (2016), 'An Overview of the GTAP 9 Data Base.' Journal of Global Economic Analysis 1(1): 181-208. https://jgea.org/resources/jgea/ojs/index.php/jgea/article/view/23

Alston, J., Pardey, P., James, J. and Andersen, M. (2009), 'The Economics of Agricultural R\&D' Annual Review of Resource Economics 1:537-66. https://doi.org/10.1146/annurev.resource.050708.144137

Anderson, K., Martin, W. and Valenzuela, E. (2006), 'The relative importance of global agricultural subsidies and market access' World Trade Review 5(3): 357-76.

Boadi, D., Benchaar, C., Chiquette, J. and Massé, D. (2004), 'Mitigation strategies to reduce enteric methane emissions from dairy cows: Update review' Canadian Journal of Animal Science 84: 319-335.

Decreux, Y. and Valin, H. (2007), 'MIRAGE, Updated Version of the Model for Trade Policy Analysis Focus on Agriculture and Dynamics' CEPII Working Paper 2007-15, CEPII, Paris.

Edwards, M. and Trancik, J. (2014) 'Climate Impacts of Energy Technologies Depend on Emissions Timing' Nature Climate Change 4(5): 347-52.

Fan, Shenggen, Cho, E. and Rue, C. (2018) 'Returns to public agricultural and rural investments in China' China Agricultural Economic Review 10(2):215-23, https://doi.org/10.1108/CAER-11-2017-0211

FAO (2017), Milk and Milk Products, FAO Outlook, Food and Agriculture Organization, Rome http://www.fao.org/fileadmin/templates/est/COMM_MARKETS_MONITORING/Dairy/ Documents/Food_Outlook_June_2017_Dairy_pdf

FAO (2019), FAOSTAT Emissions Database, Agriculture, http://www.fao.org/faostat/en/\#data/GT

Fellmann, T., Witzke, P., Weiss, F.,Van Doorslaer, B, Drabik, D., Huck, I., Salputra, G., Jansson, T. and Leip, A. (2018), 'Major Challenges of Integrating Agriculture into Climate Change Mitigation Policy Frameworks' Mitigation and Adaptation Strategies for Global Change 23:451-468. DOI 10.1007/s11027-017-9743-2

Freire-González, J. and Puig-Ventosa, I. (2015), 'Energy Efficiency Policies and the Jevons Paradox' International Journal of Energy Economics and Policy 5(1):69-79

Gerber, P.J., Steinfeld, H., Henderson, B., Mottet, A., Opio, C., Dijkman, J., Falcucci, A. and Tempio, G. (2013), Tackling climate change through livestock - A global assessment of emissions and mitigation opportunities. Food and Agriculture Organization of the United Nations (FAO), Rome.

Guimbard, H., Jean, S., Mimouni, M. and Pichot, X. (2012), 'MACMAP-HS6 2007, An Exhaustive and Consistent Measure of Applied Protection in 2007' Economie Internationale 2(130): 99-121. 
Hathaway, D. and Ingco, M. (1995), 'Agricultural liberalization and the Uruguay Round' in Martin, W. and Winters, L.A. eds. (1996), The Uruguay Round and the Developing Countries, Cambridge University Press, Cambridge.

Haque, M.N. (2018), 'Dietary manipulation: a sustainable way to mitigate methane emissions from ruminants' Journal of Animal Science and Technology 60(15): 1-10.

Harvey, L. (1993), 'A guide to global warming potentials' Energy Policy 21(1): 24-34.

Henderson, B. and Lankoski J. (2019), 'Evaluating the environmental impact of agricultural policies”, OECD Food, Agriculture and Fisheries Papers, No. 130, OECD Publishing, Paris. http://dx.doi.org/10.1787/add0f27c-en

Himics, M., Fellmann, T., Barreiro-Hurléa, J., Witzke, H.P., Pérez Domínguez, I., Jansson, T., and Weiss, F. (2018), 'Does the Current Trade Liberalization Agenda Contribute to Greenhouse Gas Emission Mitigation in Agriculture?’ Food Policy 76:120-9.

Hoekman, B., Martin, W. and Braga, C. eds (2009), Trade Preference Erosion: Measurement and Policy Response, Palgrave-MacMillan and the World Bank, New York and Washington DC.

Houghton, J., Meira Filho, L., Callander, B., Harris, N., Kattenberg, A. and Maskell, K. eds. (1996), Climate Change 1995: The Science of Climate Change, Cambridge University Press, Cambridge, for the Intergovernmental Panel on Climate Change.

Huang, J., Gulati, A. and Gregory, I. (2017), Fertilizer Subsidies-Which Way Forward? IFDC and FAI, Muscle Shoals, AL

Huang, Jikun, Wang, Xiaobing, Zhi, Huayong, Huang, Zhurong and Rozelle, Scott (2011) 'Subsidies and distortions in China's agriculture: evidence from producer-level data' Australian Journal of Agricultural and Resource Economics 55:53-71.

Ivanic, M. and Martin, W. (2018), 'Sectoral Productivity Growth and Poverty Reduction: National and Global Impacts' World Development 109: 429-39.

Jensen, H., Pérez Domínguez, I., Fellmann, T., Lirette, P., Hristov, J. and Philippidis, G. (2019), 'Economic Impacts of a Low Carbon Economy on Global Agriculture: The Bumpy Road to Paris' Sustainability 11(8), 2349.

Laborde, D. and Mamun, A. (2019), 'Global Database on Nominal Rate of Protection in Agriculture: 1955-2017', Powerpoint Presentation, International Food Policy Research Institute, Washington DC, 10 December.

Laborde, D., Robichaud, V. and Tokgoz, S. (2013), 'MIRAGRODEP 1.0: Technical Documentation' AGRODEP Technical Note, IFPRI, December.

Mamun, A., Martin, W. and Tokgoz, S. (2019), 'Reforming Agricultural Subsidies for Improved Environmental Outcomes' Discussion Paper, International Food Policy Research Institute, Washington DC.

Martin, W. and Alston, J. (1997), 'Producer surplus without apology?: evaluating investments in R\&D’ Economic Record 73(221):146-58, June. 
Mayrand, K., Dionne, S., Paquin, M., Pageot-LeBel, I. (2003), The Economic \& Environmental Impacts of Agricultural Subsidies: An Assessment of the 2002 US Farm Bill \& Doha Round, Unisféra Intl Centre, https://unisfera.org/en/publications_details.sn?pub=5

Mernit, J. (2018), 'How Eating Seaweed Can Help Cows to Belch Less Methane' Yale Environment 360, 2 July. https://e360.yale.edu/features/how-eating-seaweed-can-helpcows-to-belch-less-methane

Millar, N., Doll, J. and Robertson, G.P., (2014), 'Management of Nitrogen Fertilizer to Reduce Nitrous Oxide $\left(\mathrm{N}_{2} \mathrm{O}\right)$ Emissions from Field Crops', Climate Change and Agriculture Fact Sheet Series-MSU Extension Bulletin E3152, Michigan State University, November.

Neue, H. (1993), 'Methane emission from rice fields: Wetland rice fields may make a major contribution to global warming' BioScience 43 (7): 466-73.

OECD (2001), Measuring Productivity OECD Manual: Measurement of Aggregate and Industry-Level Productivity Growth, OECD, Paris.

OECD (2016), OECD's Producer Support Estimate and Related Indicators of Agricultural Support, OECD, Paris.

OECD (2018a), Agricultural Policy Monitoring and Evaluation 2018, OECD Publishing, Paris. http://dx.doi.org/10.1787/agr_pol-2018-en.

OECD (2018b), European Union: Estimates of Support to Agriculture, OECD, version of 15 Feb 2018 "The Cookbook"

http://www.oecd.org/unitedstates/producerandconsumersupportestimatesdatabase.htm

OECD (2019), Agricultural Policy Monitoring and Evaluation 2019, OECD Publishing, Paris, https://doi.org/10.1787/39bfe6f3-en.

OECD (2019), 'A Global Economic Evaluation of GHG Mitigation Policies for Agriculture' Background Paper for Joint Working Party on Agriculture and the Environment, COM/TAD/CA/ENV/EPOC(2018)7/FINAL, OECD, Paris.

Searchinger, T., Waite, R., Hanson, C. and Ranganathan, J. (2019), Creating a Sustainable Food Future: A Menu of Solutions to Feed Nearly 10 Billion People by 2050, World Resources Report, World Resources Institute, Washington DC.

Tubiello, F., (2019), 'Greenhouse Gas Emissions Due to Agriculture', in Ferranti, P., Berry, E.M., and Anderson, J.R. (eds.), Encyclopedia of Food Security and Sustainability, vol. 1, Elsevier, Amsterdam, 196-205.

UN (1992), United Nations Framework Convention on Climate Change, United Nations, New York.

Vermeulen, S. (2016), 'Agriculture is Integrated into the Paris Agreement'CGIAR Program on Climate Change, Agriculture and Food Security. https://ccafs.cgiar.org/research/annualreport/2015/agriculture-is-integrated-into-paris-unfccc-agreement

Zhang, Xiaobo and Fan, Shenggen (2004), 'How productive is infrastructure? A new approach and evidence from rural India' American Journal of Agricultural Economics 86(2): 492501. 